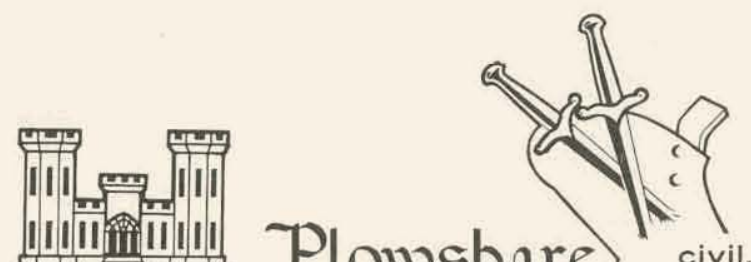

Plowsbare civil, in

UNITED STATES ARMY CORPS OF ENGINEERS

BRUNEAU PLATEAU, IDAHO

30 September 1965
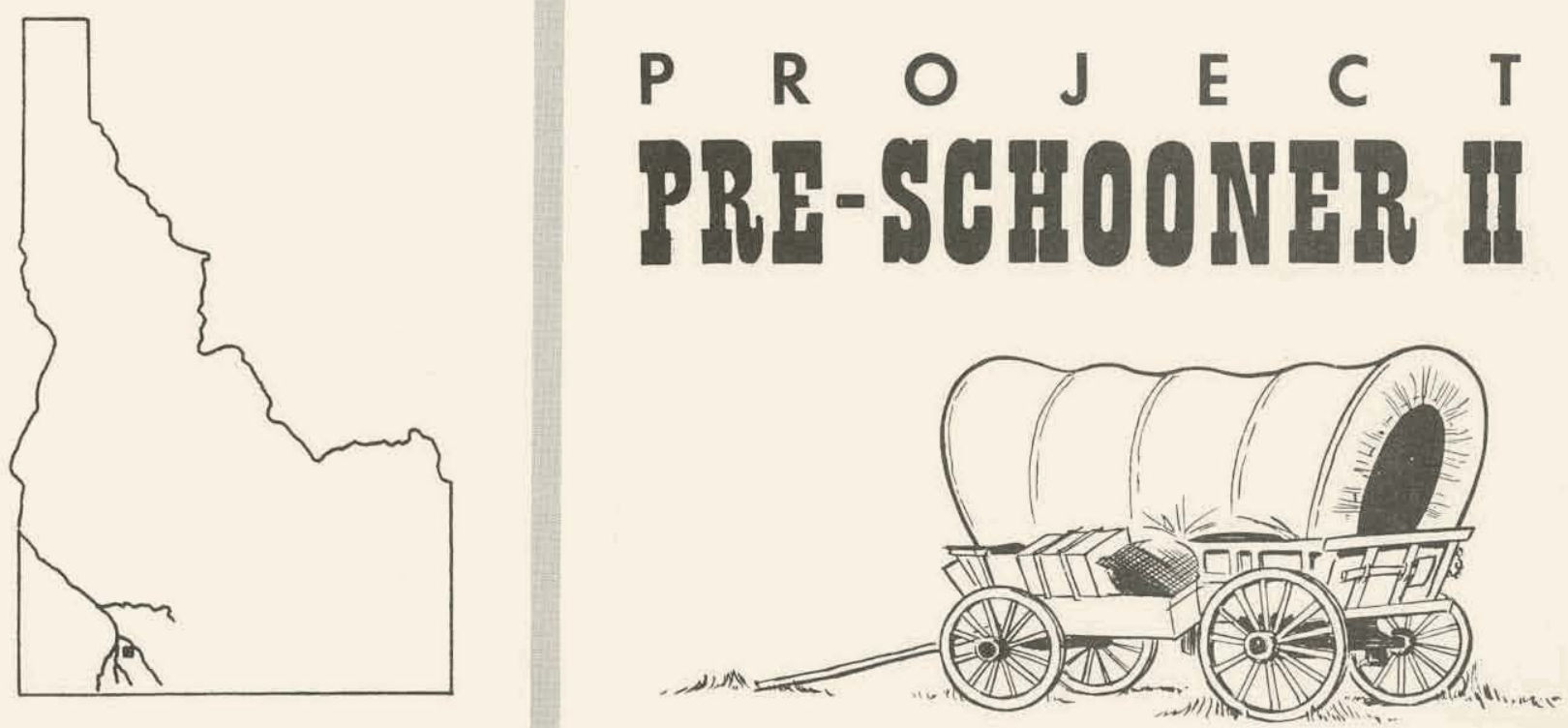

\title{
POSTSHOT GEOLOGIC AND ENGINEERING PROPERTIES INVESTIGATIONS
}

\author{
ALTON D. FRANDSEN \\ U. S. Army Engineer Nuclear Cratering Group \\ Livermore, California
}

U.S. Army Engineer Nuclear Cratering Group Livermore, California 


\section{DISCLAIMER}

This report was prepared as an account of work sponsored by an agency of the United States Government. Neither the United States Government nor any agency Thereof, nor any of their employees, makes any warranty, express or implied, or assumes any legal liability or responsibility for the accuracy, completeness, or usefulness of any information, apparatus, product, or process disclosed, or represents that its use would not infringe privately owned rights. Reference herein to any specific commercial product, process, or service by trade name, trademark, manufacturer, or otherwise does not necessarily constitute or imply its endorsement, recommendation, or favoring by the United States Government or any agency thereof. The views and opinions of authors expressed herein do not necessarily state or reflect those of the United States Government or any agency thereof. 


\section{DISCLAIMER}

Portions of this document may be illegible in electronic image products. Images are produced from the best available original document. 
Printed in USA. Available from the Clearinghouse for Federal Scientific and Technical Information, National Bureau of Standards, U. S. Department of Commerce, Springfield, Virginia 22151 Price: Printed Copy $\$ 3.00$; Microfiche $\$ 0.65$. 
PNE-516

PROJECT PRE-SCHOONER II

POSTSHOT GEOLOGIC AND ENGINEERING PROPERTIES INVESTIGATIONS
Alton D. Frandsen

U. S. Army Engineer

Nuclear Cratering Group

Livermore, California

September 1967

\section{LEGAL NOTICE}

unsored work. Neither the Unite This report was prepared as an acour of

tates, nor the Commission, nor any pertation, expressed or implied, with respect to the accuA. Makes any warranty or representaton, expressed or mined in this report, or that the use racy, completeness, or usefuiness of the infors disclosed in this report may not infringe of any information, appar

privately owned rights: $\mathrm{nr}$. B. Assumes any liabilities with respect to the use of, or for damages result

use of any information, apparatus, method, or process disclosed in this report. As used in the above, "person acting on behalf of the commistractor, to the extent that ployee or contractor of the Commission, or employee of such contractor, the the prepses, such employee or contractor of the Commission, or employee of such contractor prepsest disacminates, or proviles accese to, any infor such contractor. 


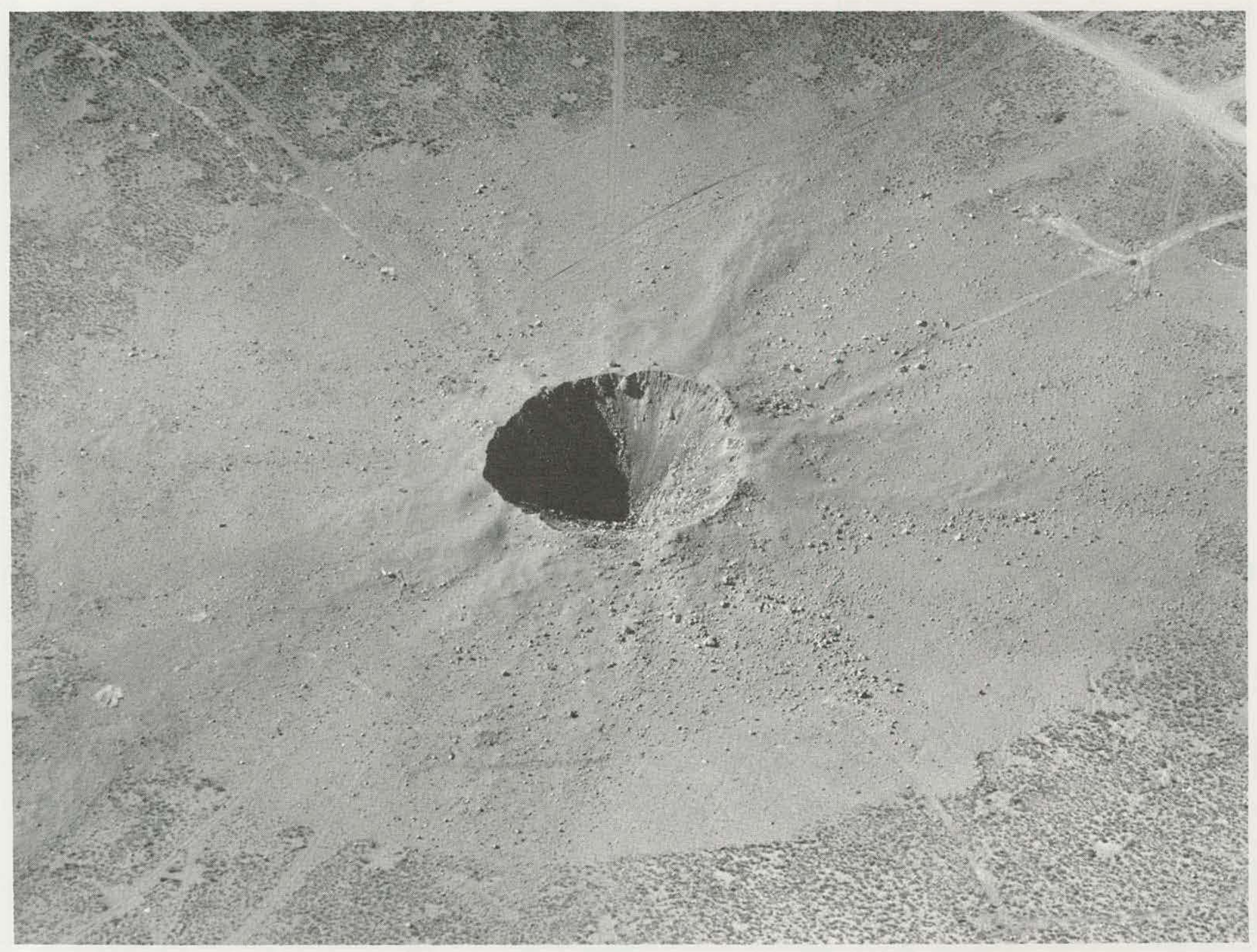

Pre-Schooner II Crater.

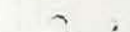




\section{ABSTRACT}

The Pre-Schooner II Event was a chemical explosive single-charge cratering experiment in hard, dry rock. The detonation was centered 71 feet below the ground surface and consisted of approximately 85.5 tons of nitromethane. The explosion produced a crater with an apparent radius of 95.2 feet and an apparent crater depth of 60.7 feet.

Postshot explorations of the crater consisted of excavating three radial trenches through the lip material and then extending two of the trenches into the fallback within the crater. Both bulk densities and block-size distribution of the ejecta and fallback were obtained. Bulk densities averaged 103.8 pcf except for an anomolous value of $93.1 \mathrm{pcf}$ in one trench. Block sizes varied from fines of clay size to blocks greater than 6 feet in diameter.

No $F$ The true crater radius and the lip upthrust were measured at the three trenches and averaged 100 feet and 11 feet, respectively.

1/ The crater slope angles measured before, during, and after completion of the No 1 fallback excavation averaged 37, 42, and 38 degrees, respectively. / 4 referencedo (awt) 
Project Pre-Schooner II was a chemical explosive cratering experiment conducted by the U. S. Army Engineer Nuclear Cratering Group as a part of the joint Atomic Energy Commission-Corps of Engineers nuclear excavation research program. This report summarizes the preshot geologic conditions at the site and presents the results of the postshot investigations. Preshot field investigations were conducted during the spring of 1965. Postshot investigations were accomplished in the spring of 1966.

Postshot investigations were performed under the supervision of A. D.. Frandsen, NCG. Directors of NCG during conduct of the study and preparation of this report were Lieutenant Colonel W. J. Slazak and Lieutenant Colonel-M. K. Kurtz, Jr. 
CONTENTS

ABSTRACT . . . . . . . . . . . . . . . . . . 3

PREFACE

CHAPTER 1 - INTRODUCTION

1.1 Description of Project

1.2 Purpose and Scope of Postshot Investigations

1.3 Scope of Report

1.4 Background

1.5 Project Location and Accessibility

CHAPTER 2 - PRESHOT SITE CONDITIONS .

2.1 Geology and Physiography

2.1.1 Vitrophyre

2.1.2 Vitrophyre Breccia

2.1.3 Felsite

2.1.4 Overburden

2.2 Physical Test Data

2.3 Field Data

2.3.1 Geophysical Test Results

2.3.2 Borehole Logs

2.3.3 Borehole Photography

2.3.4 Examination of Emplacement Hole and Explosive Cavity

CHAPTER 3 - POSTSHOT INVESTIGATIONS

3.1 Scope of Investigations

3.2 Sequence of Execution

3.3 Excavation Procedures

3.4 Bulk Densities

3.4.1 Weighing Procedures

3.4.2 Volume Determinations

3.5 Grain Size Distribution

3.6 Trench Mapping

CHAPTER 4 - POSTSHOT RESULTS AND DISCUSSIONS

4.1 Bulk Density

4.2 Grain Size Distribution

4.3 Trench Mapping

4.4 General Observations

4.4.1 Slope Adjustments Prior to Postshot Excavations

4.4.2 Slope Adjustments During Postshot Excavations . . . 43

4.4.3 S'lope Angles

CHAPTER 5 - CONCLUSIONS

REFERENCES

APPENDIX A - RESULTS OF PRESHOT UPHOLE SEISMIC SURVEY

APPENDIX B - PRESHOT BORING LOGS OF PRE-SCHOONER II

SITE AREA

APPENDIX C - LIST OF PRE-SCHOONER II REPORTS 
CONTENTS (Continued)

\section{FIGURES}

Frontispiece Pre-Schooner II crater

1.1 Location and access map

2.1 Location of geophysical surveys and boreholes

2.2 Average physical properties of media at Pre-Schooner II Site ${ }^{\circ}$

2.3 Log of emplacement hole . . . . . . . . . . . 17

3.1 Location of trenches . . . . . . . . . . . . 22

Postshot aerial photo prior to commencing excavations
(photos grouped for stereoscopic viewing)

3.3 Postshot topographic map prior to commencing excavations . 24

Aerial photo prior to excavation of fallback (photos paired
for stereoscopic viewing)

3.5 Topographic map prior to excavation of fallback $\quad . \quad$. $\quad . \quad 26$

Aerial photo after completion of all excavations (photos
grouped for stereoscopic viewing) . .

3.7 Topographic map after completion of all excavation . . . . $\quad 28$

3.8 Typical cross sections for various stages of trench

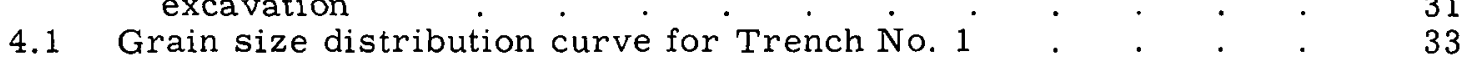

4.2 Grain size distribution curve for Trench No. $2 \quad$. . . . . . . 34

4.3 Grain size distribution curve for Trench No. $3 \quad$. . . . . . $\quad 34$

4.4 Grain size distribution curve for crater fallback . . . . . $\quad 35$

4.5 Comparison of predicted block size for two major
materials, and postshot fallback and ejecta mechanical analyses . . . . . . . 36

4.6 Ground profiles from Trench No. $1.3 . \quad . \quad . \quad . \quad . \quad . \quad 38$

4.7 Ground profiles from Trench No. 2, west wall . . . . . 39

4.8 Ground profiles from Trench No. 2, east wall . . . . . 40

4.9 Ground profiles from Trench No. $3 \quad$. . . . . . . . 41

4.10 Diagramatic segregation of block sizes in crater . . . . 43

4.11 Diagramatic illustration of mode of failure during fallback . . 43

4.12 Profiles bearing $\mathrm{S} 40^{\circ} \mathrm{W}$ of apparent crater illustrating

4.13 Aerial photo 14 months after completion of all excavation . $\cdot$. $^{\circ} \quad 45$

4.14 Topographic map 14 months after completion of excavation . 46

A1 Average velocities (slant-distance corrected) . . . . . 53

A2 Internal velocities . . . . . . . . . . . . . 54

A3 verage velocities from shot to surface (slant-distance
corrected) . . . . . . 55

TABLES

1.1 Data on Craters for Which Engineering Properties Investigations Have Been Performed

2.1 Stratigraphic Sequence

2.2 Summary of Preshot Physical Test Data . . . .

2.3 Tabulation of Preshot Boring Coordinates and Depths $\cdot \cdot \cdot \cdot 13$

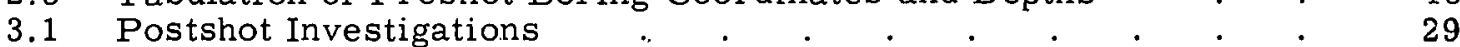

4.1 Summary of Bulk Densities . . . . . . . . . . . . $\quad$. 33

4.2 Distribution of Rock Type in Lip. Ejecta with Respect to Size . $\quad 37$

4.3 Preshot Percentage Distribution of Rock Types Within Crater Area

4.4 Uplift and True Crater Radius $\cdot \cdot \cdot \cdot \cdot \cdot \cdot \cdot \cdot{ }^{\cdot} \cdot{ }^{\cdot} \quad 37$

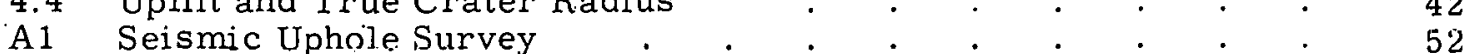


CHAPTER 1

INTRODUCTION

\subsection{DESCRIPTION OF PROJECT}

Project Pre-Schooner II was a chemical explosive, single-charge cratering experiment in hard, dry, rhyolite rock executed by the U. S. Army Engineer Nuclear Cratering Group (NCG) as a part of the joint Atomic Energy Commission-Corps of Engineers nuclear excavation research program. Pre-Schooner II was detonated on 30 September 1965 at 1709:59.2 Mountain Standard Time on Bruneau Plateau, approxi mately 40 miles southwest of Bruneau, Idaho (Figure 1.1). The emplacement hole was at the following coordinates: Longitude W $115^{\circ} 34^{\prime} 25.203^{\prime \prime}$; Latitude N 42 $24^{\prime} 02.943^{\prime \prime}$ (Modified Idaho State Coordinate System - N 267,639.53; E 547,783.11). The cavity, centered at a depth of 71 feet below ground surface, contained approximately 85.5 tons of nitromethane $\left(\mathrm{CH}_{3} \mathrm{NO}_{2}\right)$ at zero time. The detonation resulted in a crater with an apparent crater radius of 95.2 feet, an apparent crater depth of 60.7 feet, and an apparent crater volume of $24,780 \mathrm{yd}^{3}$.

\subsection{PURPOSE AND SCOPE OF POSTSHOT INVESTIGATIONS}

When an excavation is produced by explosive methods, the physical properties of the surrounding media are appreciably, altered. The extent and nature of these changes are of prime importance in evaluating the usefulness of the excavation for engineering purposes. The objective of the Pre-Schooner II postshot investigations was to examine the engineering properties of the crater produced by the detonation. Data developed from these investigations will be used in the continuing program to develop methods for predicting the shape and character of the disturbed zones surrounding a crater based on the results of preshot explorations.

In order to accomplish this objective, the program was designed to obtain infor mation concerning the geometry of the crater and the characteristics of the zones of disturbance. These zones of disturbance include fallback, ejecta, and the ruptured zone beyond the true crater boundary.

The scope of the Pre-Schooner II postshot investigations included:

1. Determination of true crater dimensions by trenching through the ejecta and fallback material into the rupture zone

2. Determination of the bulk density of the ejecta by measuring the volume of, and weighing, the material excavated during trenching 

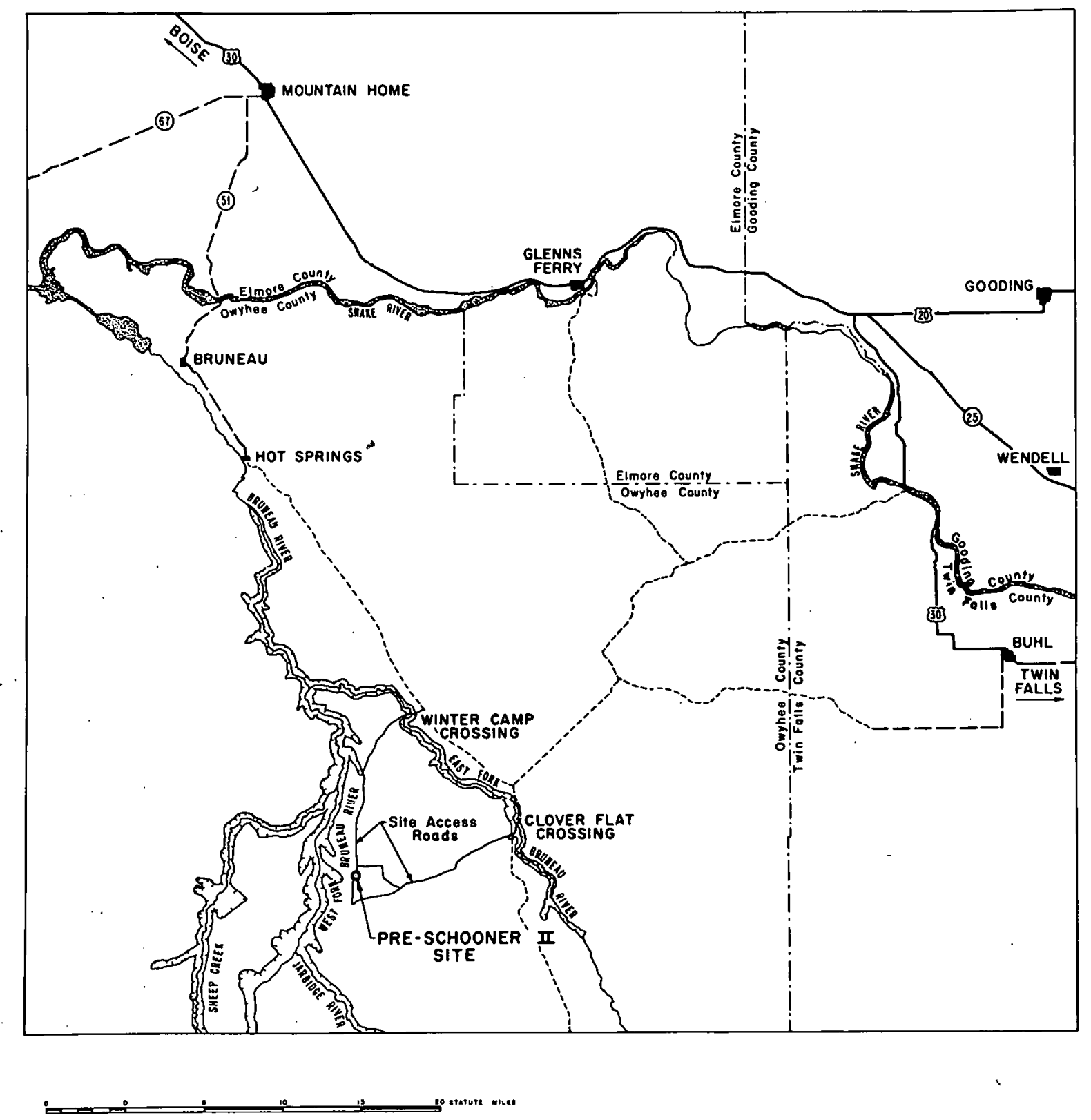

LEGEND:

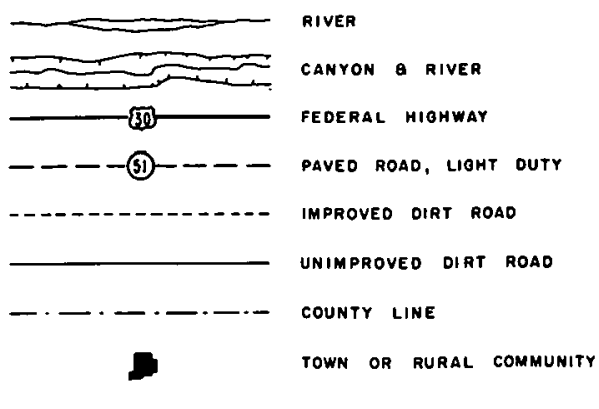

Figure 1.1 Location and access map. 
3. Determination of the size distribution of the ejecta and fallback rock fragments by sieving

4. Definition of the displaced ground.surface (lip upthrust) and true crater shape

\subsection{SCOPE OF REPORT}

This report presents a detailed explanation of exploratory techniques and results of the postshot engineering properties investigations. Preshot geologic conditions and physical properties of the media are summarized in Chapter 2. A comprehensive coverage of Pre-Schooner II preshot geology is contained in the preshot investigations report (Reference 1) of the U. S. Army Engineer Waterways Experiment Station (WES).

The major portion of the field work covered by this report was accomplished during the period 17 February to 6 May 1966.

\subsection{BACKGROUND}

A number of nuclear and chemical explosive single-charge cratering experiments and one chemical explosive multiple-charge experiment have been conducted at the Nevada Test Site (NTS) to determine cratering characteristics in alluvium and hard, noncarbonate rock. Postshot explorations similar to those undertaken at Pre-Schooner II have been performed at several of these craters (References 1 through 6). Pertinent data concerning these craters are included in Table 1.1. The Pre-Schooner II cratering

TABLE 1.1 DATA ON CRATERS FOR WHICH ENGINEERING PROPERTIES INVESTIGATIONS HAVE BEEN PERFORMED

\begin{tabular}{lcccccc} 
Craters & $\begin{array}{c}\text { Scaled } \\
\text { DOB }\end{array}$ & $\begin{array}{c}\text { Actual } \\
\text { DOB }\end{array}$ & $\begin{array}{c}\text { Apparent } \\
\text { Crater } \\
\text { Depth }\end{array}$ & $\begin{array}{c}\text { Average } \\
\text { Apparent } \\
\text { Crater Radius }\end{array}$ & $\begin{array}{c}\text { Average } \\
\text { Apparent } \\
\text { Lip Height }\end{array}$ & Yield \\
\hline $\begin{array}{l}\text { Pre-Schooner } \\
\text { Delta }\end{array}$ & 135 & 42.7 & 25.6 & 46.1 & & tons \\
$\begin{array}{l}\text { Pre-Schooner } \\
\quad \text { Charlie }\end{array}$ & 210 & 66.5 & -1.3 & none & 16.0 & 20 \\
$\begin{array}{l}\text { Dugout } \\
\text { Sulky }\end{array}$ & 185 & 59 & $34 \pm 5$ & $129 \pm 8$ & $24 \pm 5$ & 100 \\
$\begin{array}{l}\text { Danny Boy } \\
\text { Pre-Schooner II }\end{array}$ & 185 & 90 & -9.2 & none & 20.9 & $85 \pm 15$ \\
\hline
\end{tabular}

${ }^{a}$ Row crater containing five 20 -ton charges

$\mathrm{b}_{\text {Nuclear }}$

event was a single-charge cratering experiment in a rock medium less competent than the basalt of Buckboard Mesa at NTS; therefore, a postshot exploration of the crater was expected to provide meaningful data pertaining to the engineering properties of a crater in a different rock medium. 


\subsection{PROJECT LOCATION AND ACCESSIBILITY}

The Pre-Schooner II Event was located in Owyhee County of southwestern Idaho. The site is roughly 65 road miles south of Mountain Home, Idaho. Figure 1.1 is an index map showing the site location and access roads. 


\section{CHAPTER 2}

PRESHOT SITE CONDITIONS

Extensive preshot surface and subsurface explorations were made at the Pre-Schooner II site. These explorations include surface geologic mapping and access hole logging (References 7 and 8), subsurface core-hole drilling and refraction seismic surveying (Reference 1), and uphole seismic surveys (Reference 9). General geology and physiography of the region are treated in References 10 and 11 . The following paragraphs summarize information contained in the above references.

\subsection{GEOLOGY AND PHYSIOGRAPHY}

The Pre-Schooner II site is located in a region commonly known as the Bruneau Desert. It is an area of gently northward sloping topography with occasional low, rounded hills interrupting the monotonous sage-covered ground surface. Canyons of the Bruneau River and its tributary streams flowing through the region are narrow and deep with precipitous, near vertical walls. In the vicinity of the Pre-Schooner II site, the West Fork of the Bruneau River is approximately 800 feet deep.

Bedrock in this region of southwestern Idaho consists of a variety of clastic and volcanic rocks ranging in age from Miocene to Recent. Bedrock relationships in the vicinity of the Pre-Schooner II site are shown in Table 2.1.

TABLE 2.1 STRATIGRAPHIC SEQUENCE

\begin{tabular}{|c|c|c|}
\hline Formation & Age & Description \\
\hline Recent Flows & Upper Pliocene to Recent & $\begin{array}{l}\text { Local patches or domes of } \\
\text { basaltic flows }\end{array}$ \\
\hline Banbury Basalt & Middle Pliocene & $\begin{array}{l}\text { Basalt and interbed } \\
\text { lacustrine deposits }\end{array}$ \\
\hline Idavada Volcanics & $\begin{array}{l}\text { Upper Miocene to } \\
\text { Lower Pliocene }\end{array}$ & Acidic volcanics \\
\hline
\end{tabular}

The immediate Pre-Schooner II area is in the Idavada formation which, in general, consists primarily of interbedded silicic latite flows, glassy rhyolite flows, and lava flows.

At the site, to the depths drilled, bedrock is mineralogically a porphyritic glassy rhyolite which has commonly been subdivided into the following textural variations: vitrophyre, vitrophyre breccia, and felsite. A thin blanket of overburden covers most of the area. 
2.1.1 Vitrophyre. This rock type typically consists of a finely divided black ground mass containing 10 to 20 percent plagioclase phenocrysts by volume. The plagioclase is primarily lath-shaped oligoclase ranging in size from less than $1 / 64$ to $3 / 8$ inch. Texturally, the vitrophyre ranges from dense to vesicular with local zones which are even highly scoriaceous. Perlitic fracturing throughout the vitrophyre makes it very friable and easily crumbled by light blows with a hammer or rubbing between the fingers. When shattered, it breaks down to fragments as small as coarse sand. Iron stains coating the perlitic fractures often give hand specimens the appearance of being red. Infrequent joint faces are generally coated with calcareous material and clayey alteration products.

Thickness of the vitrophyre, including the vitrophyre breccia, ranges from 0 to 45 feet. Average thickness in the area drilled is about 25 feet.

2.1.2 Vitrophyre Breccia. Mineralogically, the vitrophyre breccia is essentially the same as the vitrophyre. Physically, it is a distinctly different rock type. Core samples show the breccia to be a conglomeration of black glassy vitrophyre fragments ranging from sand size to several feet in diameter enclosed in a reddish brown, finely divided, glassy matrix. Petrographic analysis shows the mineralogical composition of the fragments and matrix to be essentially the same. The fragments contain the same type of feldspar phenocrysts and perlitic cracking as found in the vitrophyre.

Stratigraphically and areally, the breccia is irregular, occurring both above and below the vitrophyre at some localities and is totally absent in other places. The lack of breccia, as recorded in some holes, may be due to a lower core recovery percentage in those particular holes.

2.1.3 Felsite. The felsite is typically a hard, dense rock, pinkish gray to light gray. At the Pre-Schooner II site it normally underlies the vitrophyre, or vitrophyre breccia, where present. Mineralogically, the felsite is classified as a porphyritic rhyolite, as are the vitrophyre and breccia. It differs considerably in physical properties and texture from the other types.

Phenocrysts are usually less numerous in the felsite, and perlitic fracturing occurs only in localized pods rather than throughout the rock mass.

Joints occur as irregular, coalescing, and bifurcating curved surfaces, sometimes healed with calcite and sometimes entirely free of any secondary coating. In most cases, however, preshot joints were fairly tight as seen in the shot cavity and access hole.

2.1.4 Overburden. The overburden in the Pre-Schooner II area consists of sandy silt and fragments of the three different rock types. Thickness of the overburden ranges from 0 to 10 feet and averages about 6 feet over the area of the crater. 


\subsection{PHYSICAL TEST DATA}

The preshot physical test data are tabulated in Table 2.2 according to the three major rock types. An examination of the table indicates several trends:

1. The specific gravity of the three rock types varies slightly (the vitrophyre breccia is the lowest and the felsite the highest).

2. The bulk density (dry and saturated surface dry) is approximately the same for the felsite and vitrophyre, excluding the vesicular vitrophyre, and slightly lower for the vitrophyre breccia.

3. Average unconfined compressive strength is lowest for the vitrophyre breccia and only slightly higher for the vitrophyre, whereas the average strength of the felsite is considerably higher.

4. The modulus of elasticity increases gradually from the apparently weaker and less dense vitrophyre breccia to the felsite.

TABLE 2.2 SUMMARY OF PRESHOT PHYSICAL TEST DATA

\begin{tabular}{|c|c|c|c|c|c|c|c|c|c|}
\hline $\begin{array}{l}\text { Boring } \\
\text { Number }\end{array}$ & $\operatorname{Depth}^{\mathrm{a}}$ & Description $^{b}$ & $\begin{array}{l}\text { Bulk D } \\
\text { SSD }\end{array}$ & $\begin{array}{c}\text { Density } \\
\text { Dry }\end{array}$ & $\begin{array}{l}\text { Specific } \\
\text { Gravity }\end{array}$ & Porosity & $\begin{array}{l}\text { Unconfined } \\
\text { Compressive } \\
\text { Strength }\end{array}$ & $\begin{array}{l}\text { Modulus of } \\
\text { Elasticity }\end{array}$ & $\begin{array}{l}\text { Poisson's } \\
\text { Ratio }\end{array}$ \\
\hline & feet & & pcf & pcf & & percent & psi & psi $\times 10^{6}$ & 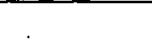 \\
\hline \multicolumn{10}{|c|}{ Vitrophyre } \\
\hline 2.1 & 18.1 & Massive Vitrophyre & 152 & 150 & 2.44 & 1.6 & 7,320 & 3.13 & 0.18 \\
\hline 2.1 & 26.6 & Lithoidal Vitrophyre & 153 & 149 & 2.50 & 4.8 & 3,820 & 0.84 & $-c$ \\
\hline 2.1 & 43.7 & Vesicular Vitrophyre & 134 & 130 & 2.43 & 14.4 & 3,090 & 2.50 & 0.25 \\
\hline 2.6 & 19.7 & Layered Vitrophyre & 150 & 147 & 2.49 & 5.8 & 6,830 & 2.47 & 0.10 \\
\hline \multirow[t]{2}{*}{2.8} & 8.4 & Massive Vitrophyre & 149 & 146 & 2.49 & 5.9 & 9,010 & 5.77 & 0.24 \\
\hline & & Average & 148 & 144 & 2.47 & 6.5 & 6,014 & 2.94 & 0.19 \\
\hline \multicolumn{10}{|c|}{ Vitrophyre Breccia } \\
\hline 2.3 & 43.7 & Vitrophyre Breccia & 141 & 137 & 2.40 & 8.4 & 4,450 & 2.44 & 0.24 \\
\hline \multirow[t]{2}{*}{2.3} & 44.2 & Vitrophyre Breccia & 142 & 138 & 2.43 & 9.1 & 6,410 & 2.46 & 0.16 \\
\hline & & Average & 142 & 138 & 2.42 & 8.7 & 5,430 & 2.45 & 0.20 \\
\hline \multicolumn{10}{|l|}{ Felsite } \\
\hline 2.1 & 86.5 & Layered Felsite & 150 & 148 & 2.54 & 6.7 & 19,710 & 4.94 & 0.19 \\
\hline 2.1 & 109.7 & Layered Felsite & 152 & 150 & 2.52 & 4.8 & $-c$ & $-c$ & $-{ }^{c}$ \\
\hline 2.10 & 26.9 & Glassy Felsite & 147 & 141 & 2.49 & 9.1 & 5,970 & 1.20 & 0.21 \\
\hline 3.10 & 31.8 & Layered Felsite & 152 & 147 & 2.52 & 6.5 & 7,730 & 2.29 & $-c$ \\
\hline 2.10 & 77.4 & Massive Felsite & 153 & 149 & 2.56 & 6.6 & 21,940 & 4.68 & 0.20 \\
\hline \multirow[t]{2}{*}{2.10} & 108.8 & Massive Felsite & 154 & 150 & 2.54 & 5.5 & 17,050 & 4.59 & 0.15 \\
\hline & & Average & 152 & 147 & 2.53 & 6.5 & 14,480 & 3.54 & 0.19 \\
\hline
\end{tabular}

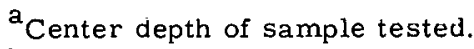

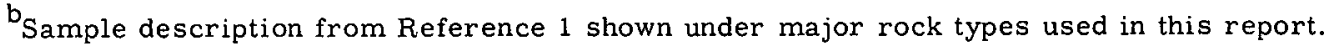

${ }^{c}$ Data shown as doubtful in Reference 1, malfunction of test equipment, or unable to run test with available sample. 


\subsection{FIELD DATA}

Information on subsurface conditions at the Pre-Schooner II site was obtained in the field by geophysical methods, core logging, borehole photography, and examination of the emplacement hole and explosive cavity.

2.3.1 Geophysical Test Results. An uphole seismic survey was run in borehole 2.12 (Figure 2.1). Explosive charges of 1-1/2 pounds each were successively detonated at 10 -foot intervals, and the results presented in Appendix A were obtained. A summary of the seismic velocities obtained from the uphole seismic survey is given in Figure 2.2 together with the average physical properties of the media as determined from laboratory tests. The summary shows a fairly good correlation.

In addition to the uphole survey, two surface refraction seismic traverses were run along the lines shown on Figure 2.1. Discussion of these data appears in Reference 1.

2.3.2 Borehole Logs. Twelve preshot borings were made at the project site. Locations of the borings are shown in Figure 2.1, and Table 2.3 gives the boring coordinates and drilled depth. Five of the borings (2.1,2.7, 2.10, 2.11 and 2.12) were within the immediate vicinity of the crater, and the detailed logs of these borings are included as Appendix B. Detailed lithologic logs of all borings in the Pre-Schooner II area and borings drilled during the site selection phase of the Pre-Gondola II project are contained in an appendix to the WES preshot report (Reference 1). Examination of the logs shows very poor core recovery in the upper part of the borings which indicate a rather weak, friable material.

The boring logs in Appendix B show that the felsite generally occurs 20 to 50 feet below the surface. However, a rock outcrop some 30 feet to the northwest of SGZ is felsite, which indicates that the combined thickness of vitrophyre and vitrophyre breccia is highly variable in the site area. Overburden thicknesses within the site area varied from 0 to as much a 10 feet within 100 feet of SGZ.

2.3.3 Borehole Photography. Borehole photographs were made in the borings in the immediate vicinity of the Pre-Schooner II site. Due to the fact that the holes were made oversize by rod whip during drilling, no useful data were obtained.

2.3.4 Examination of Emplacement Hole and Explosive Cavity. In addition to the core logs, the ground zero emplacement hole, a 36-inch diameter calyx boring, and the shot cavity were visually examined. Results of the access hole and shot cavity inspection are shown in Figure 2.3. 


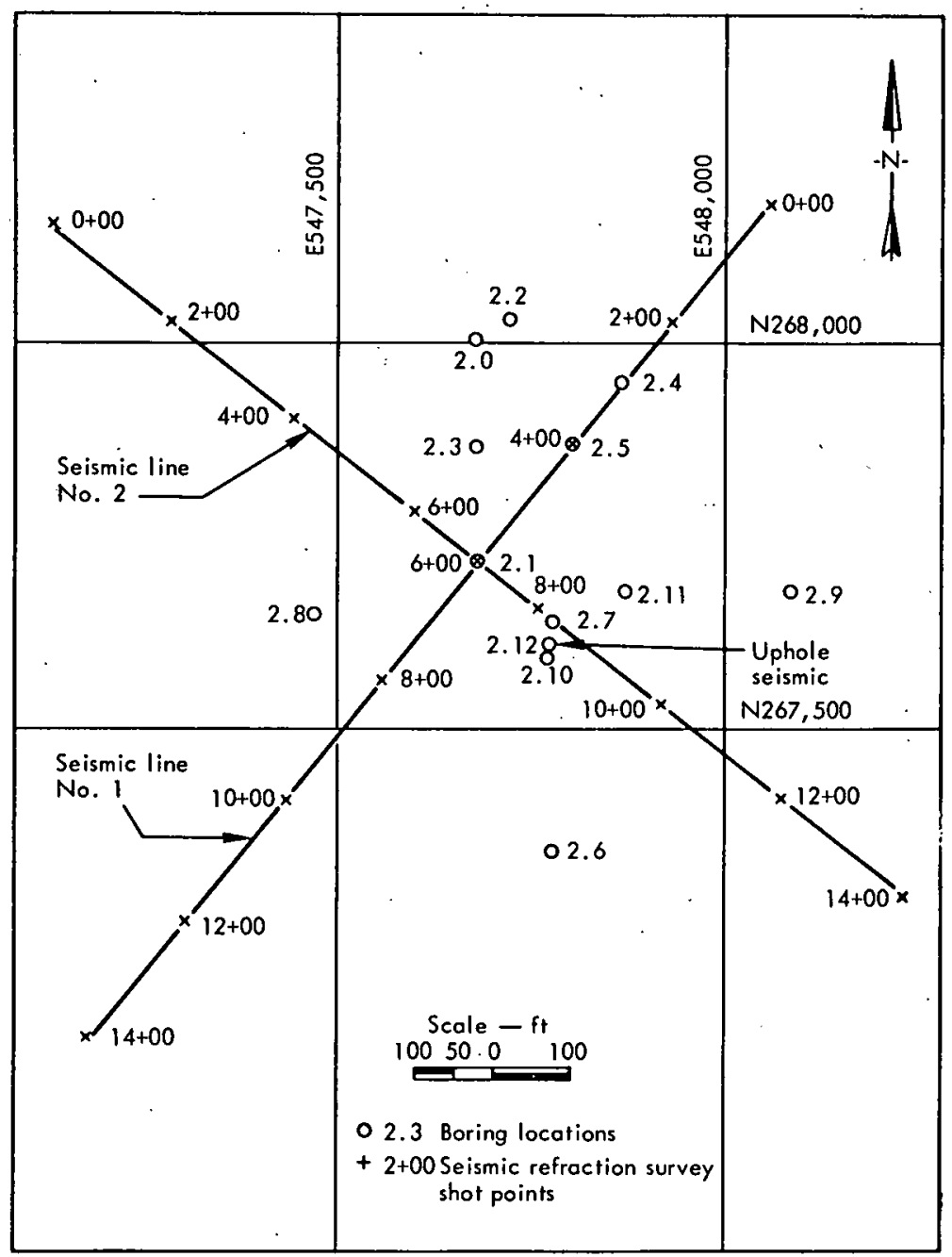

Figure 2.1 Location of geophysical surveys and boreholes.

TABLE 2.3 TABULATION OF PRESHOT BORING COORDINATES AND DEPTHS

\begin{tabular}{lccccc}
\hline $\begin{array}{c}\text { Boring } \\
\text { Number }\end{array}$ & \multicolumn{2}{c}{ Coordinates } & $\begin{array}{c}\text { Collar } \\
\text { Elevation }\end{array}$ & $\begin{array}{c}\text { Total } \\
\text { Depth }\end{array}$ & $\begin{array}{c}\text { Depth of } \\
\text { Overburden }\end{array}$ \\
\cline { 3 - 5 } & & East & & feet & feet \\
2.0 & $268,006.0$ & $547,668.9$ & 4623.2 & 49.5 & 3.8 \\
2.1 & $267,719.7$ & $547,681.0$ & 4627.8 & 150.0 & 7.8 \\
$\dot{2} .2$ & $268,031.1$ & $547,711.9$ & 4623.4 & 89.4 & 2.0 \\
2.3 & $267,865.7$ & $547,674.3$ & 4625.0 & 71.3 & 8.4 \\
2.4 & $267,953.1$ & $547,868.2$ & 4624.4 & 10.0 & 2.8 \\
2.5 & $267,877.3$ & $547,805.4$ & 4625.6 & 29.8 & 2.4 \\
2.6 & $267,339.5$ & $547,784.2$ & 4633.4 & 27.8 & 3.6 \\
2.7 & $267,639.5$ & $547,783.1$ & 4629.4 & 105.0 & 7.0 \\
2.8 & $267,630.9$ & $547,477.9$ & 4628.9 & 27.3 & 7.0 \\
2.9 & $267,693.0$ & $548,079.1$ & 4629.2 & 40.0 & 5.8 \\
2.10 & $267,589.3$ & $547,776.0$ & 4629.9 & 115.0 & 8.2 \\
2.11 & $267,697.5$ & $547,870.4$ & 4629.0 & 90.0 & 10.0 \\
2.12 & $267,609.8$ & $547,778.9$ & 4629.7 & 120.0 & 6.0 \\
\hline
\end{tabular}

${ }^{\text {a }}$ Elevation above MSSL scaled from topographic map. 


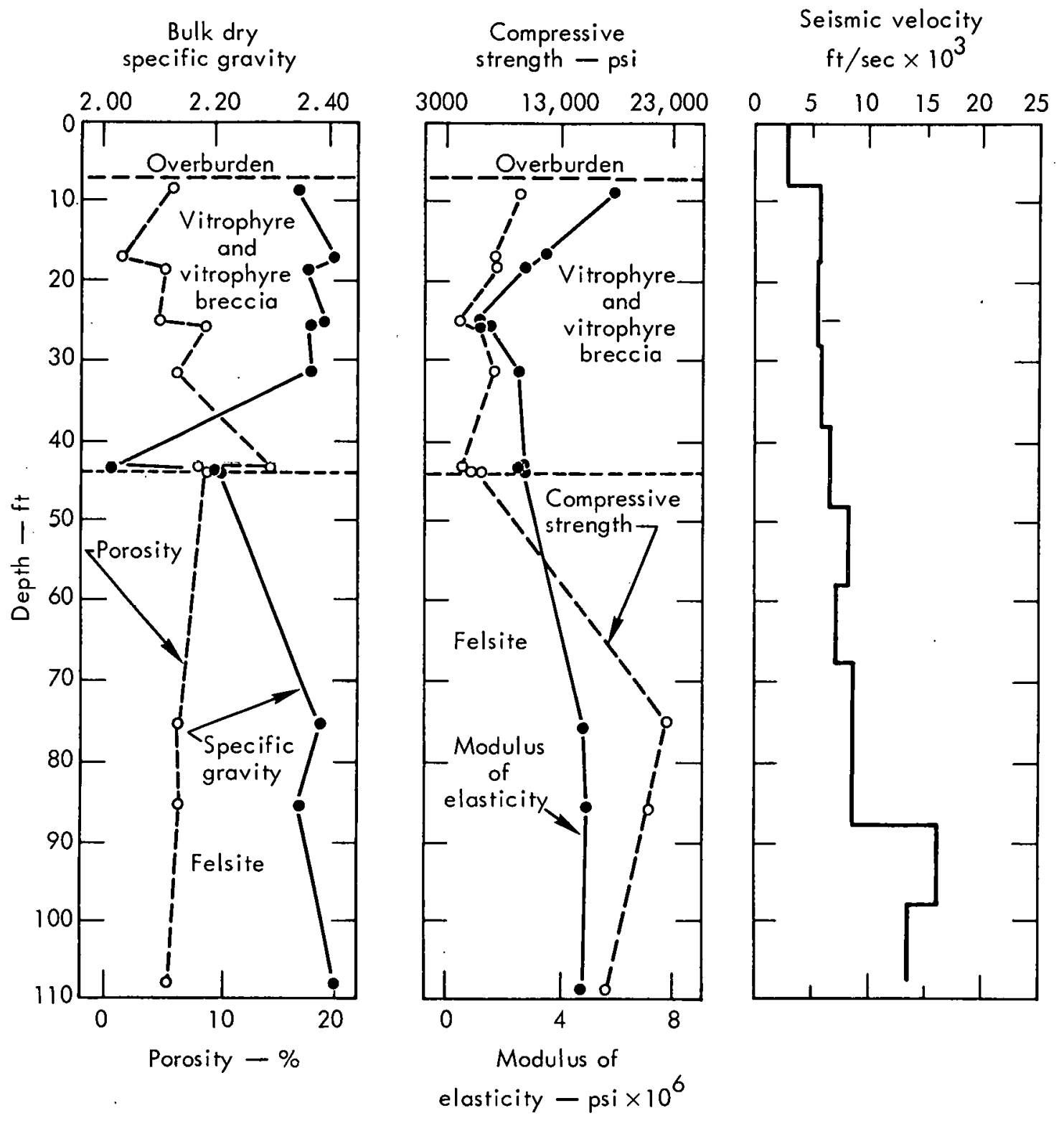

Figure 2.2 Average physical properties of media at Pre-Schooner II site (Reference 12). 
North East South West North

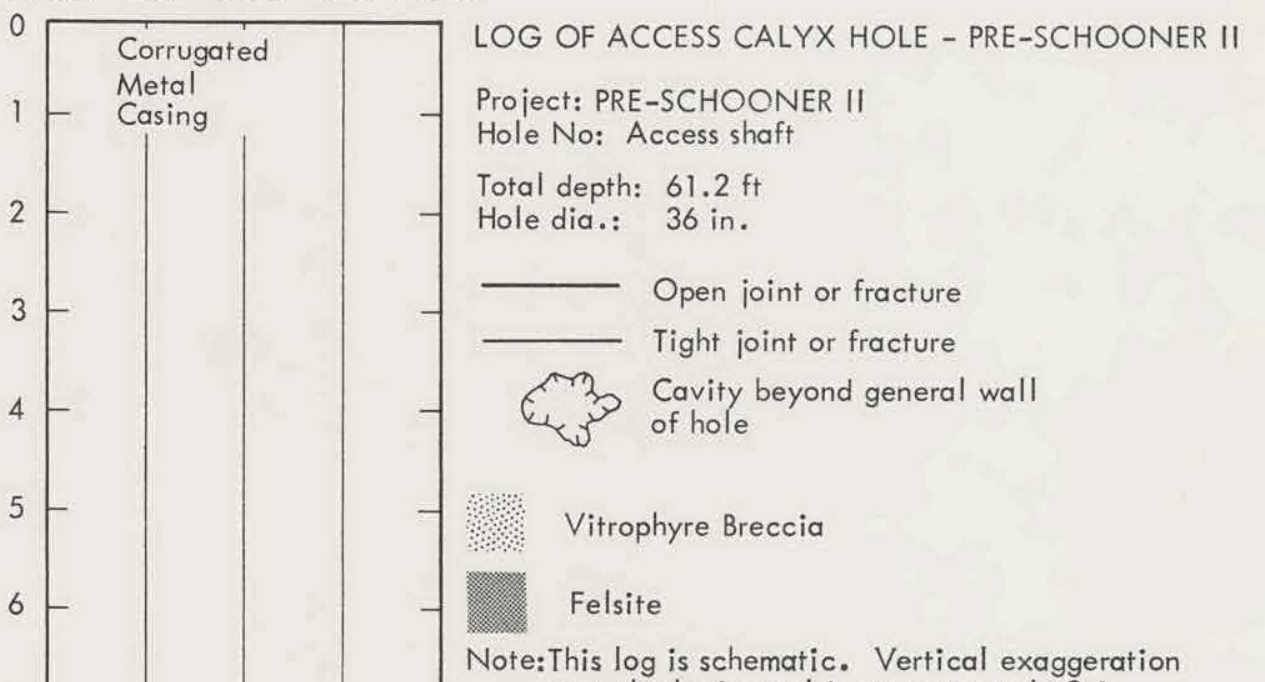

Note: This log is schematic. Vertical exaggeration
over the horizontal is approximately $2: 1$.

Photo insets show the general character of the rock.

\section{Bottom of casing}

Hole in concrete coating exposing highly

altered volcanic glass
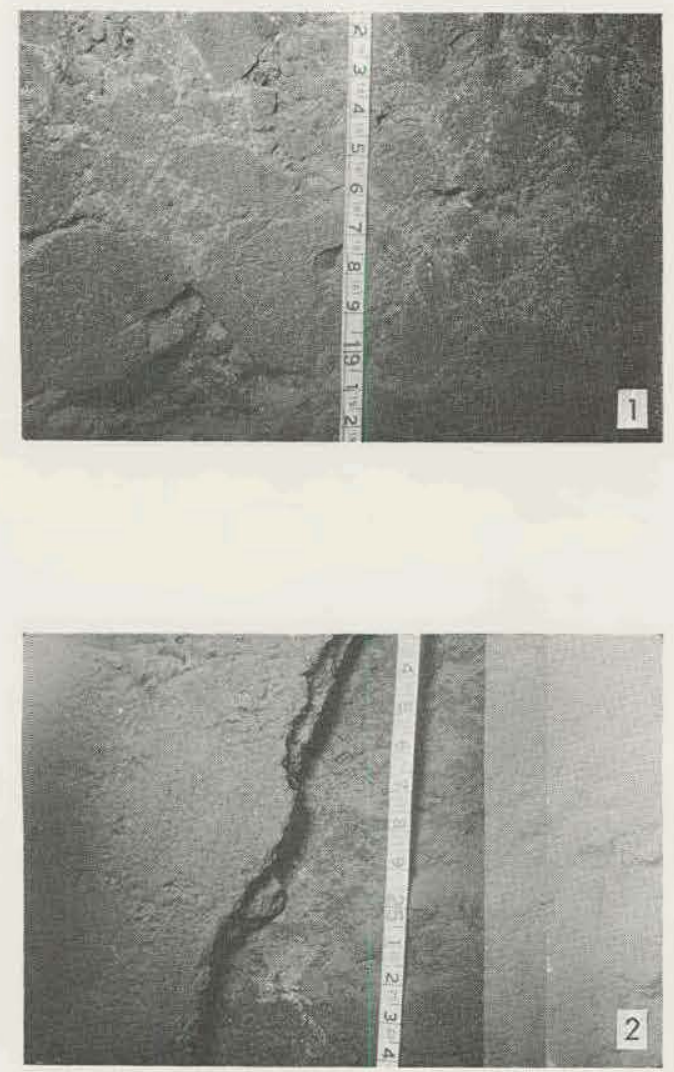

2
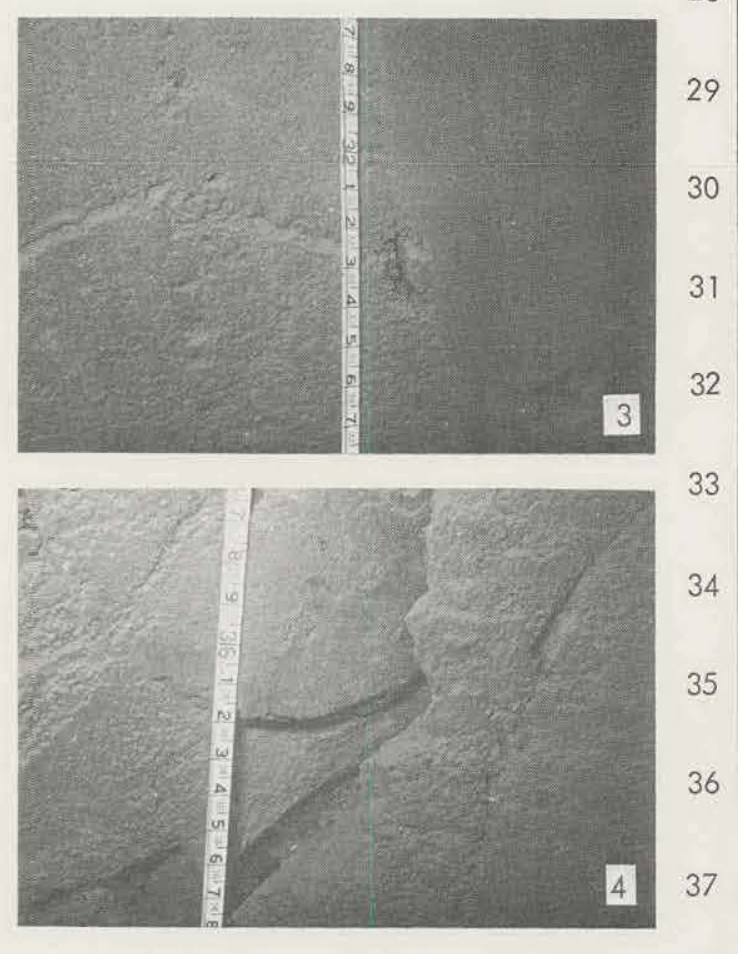

10

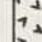

11

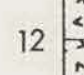

13

14

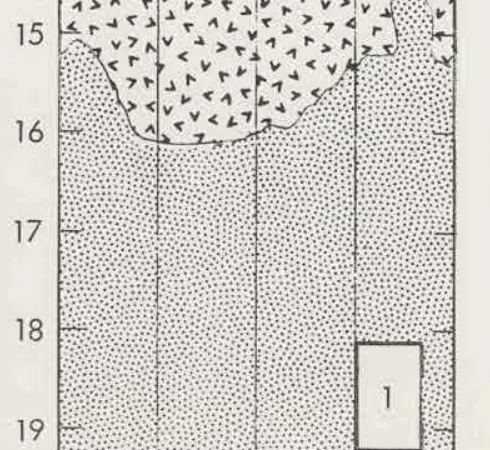

$5<$

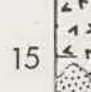

25

Ghly altered, crumbly, oxide stained, waxy glass matrix holding angular fragments of black volcanic glass or obsidian ranging from 0.02 to $.8 \mathrm{ft}$ maximum dimension.

Solid welded mass with few recognizable joints or fractures. Walls of the hole are pitted where the drilling process has eroded the softer matrix.

Exposed fragments of highly fracture felsite with maximum dimension $1 \mathrm{ft}$.

A prominent structural plane enters the hole from the SW. It is open to $2 \mathrm{in}$. with one smooth planar wall (N. side) and one wall of crushed rock. Plane migrates across the hole leaving through north wall at $41.7 \mathrm{ft}$.

\section{reximate cont \\ Approximate contact; gradational,} breccia of $26 \mathrm{ft}$ to $29 \mathrm{ft}$. Matrix of the breccia fapid changes from small black obidiad changes from small black obsidian fragments in altered glass matrix to
uniform glassy to aphanitic, porphyritic, uniform glassy to a

Near the top of the sequence the felsite is characterized by a hard, glassy matrix with subhedral to anhedral white and black phenocrysts. With depth, the matrix becomes more crystalline and darker in color. The phenocrysts become more euhedral.

The rock is permeated by small fracture planes similar to conchoidal fracturing in obsididan. Fairly good cohesion along these planes. 


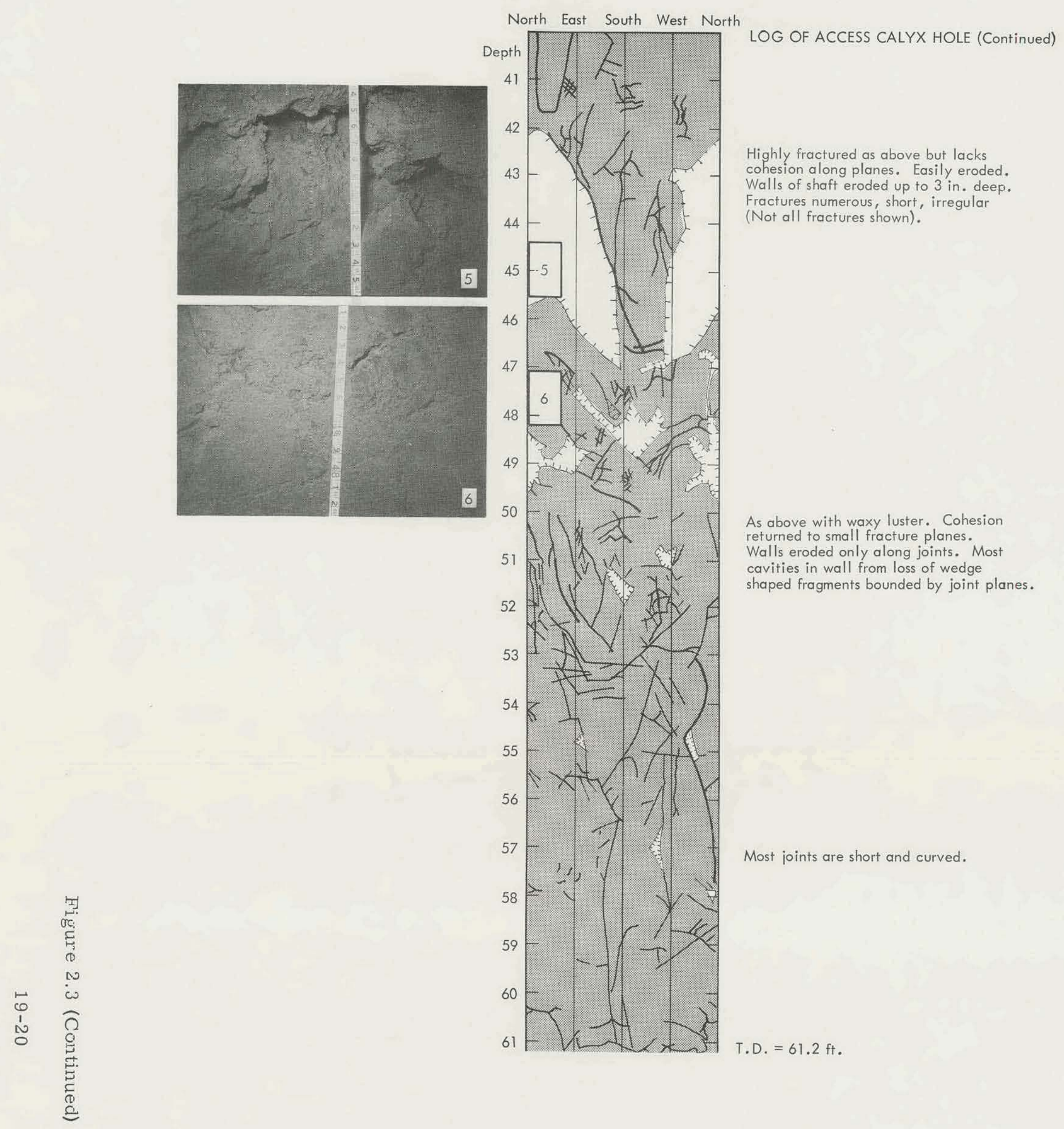


CHAPTER 3

POSTSHOT INVESTIGATIONS

Postshot investigations consisted of excavation in the ejecta, upthrust, and fallback in order (1) to determine bulk density and grain size distribution and (2) to examine the upthrust, fallback, and rupture zone.

In excavating through the lip, every effort was made to avoid picking up any of the overburden which was part of the original ground. This was fairly easy to do in the outer parts of the trenches because of the marked differences between the ejecta and overburden. However, in the end of the trenches nearest the crater there was some mixing of overburden with ejecta due to the greater difficulty in locating and following the contact.

\subsection{SCOPE OF INVESTIGATIONS}

Three trenches (see Figure 3.1) were excavated through the lip. Bulk densities were obtained for the ejecta, and an attempt was made to determine the bulk density of the upthrust. Part of the material excavated was used for determination of grain size distribution. In addition, the trenches exposed profiles of the upthrust ground surface. Detailed mapping of these profiles was accomplished to assist in determining the engineering properties of the crater lip.

Trenches No. 1 and No. 3 were extended to the middle of the crater (Figure 3.1) to measure bulk density, and grain size distribution, and to expose the rupture zonefallback contact.

\subsection{SEQUENCE OF EXECUTION}

The postshot exploratory field work began by obtaining an aerial photograph of the crater and ground surveys for the three trench areas. The ejecta above the upthrust original ground surface was then excavated from the trenches. Trench areas were then surveyed again, and the upthrust lip material was removed, bringing the trench floors down to several feet below the original ground elevation. The trench areas were then surveyed for the third time.

After the trenches were completed and final surveys made, a major portion of the lip material between the trenches was moved away from the edge of the apparent crater, and aerial photographs and a topographic map were obtained. Excavation of the fallback inside the crater was then started. When sufficient material had been excavated for a bulk density determination and before excavating into the rupture zone, another set of aerial photographs and a topographic map were made. Excavation then proceeded into the rupture zone. Eventually, the original three trenches were deepened as far as 


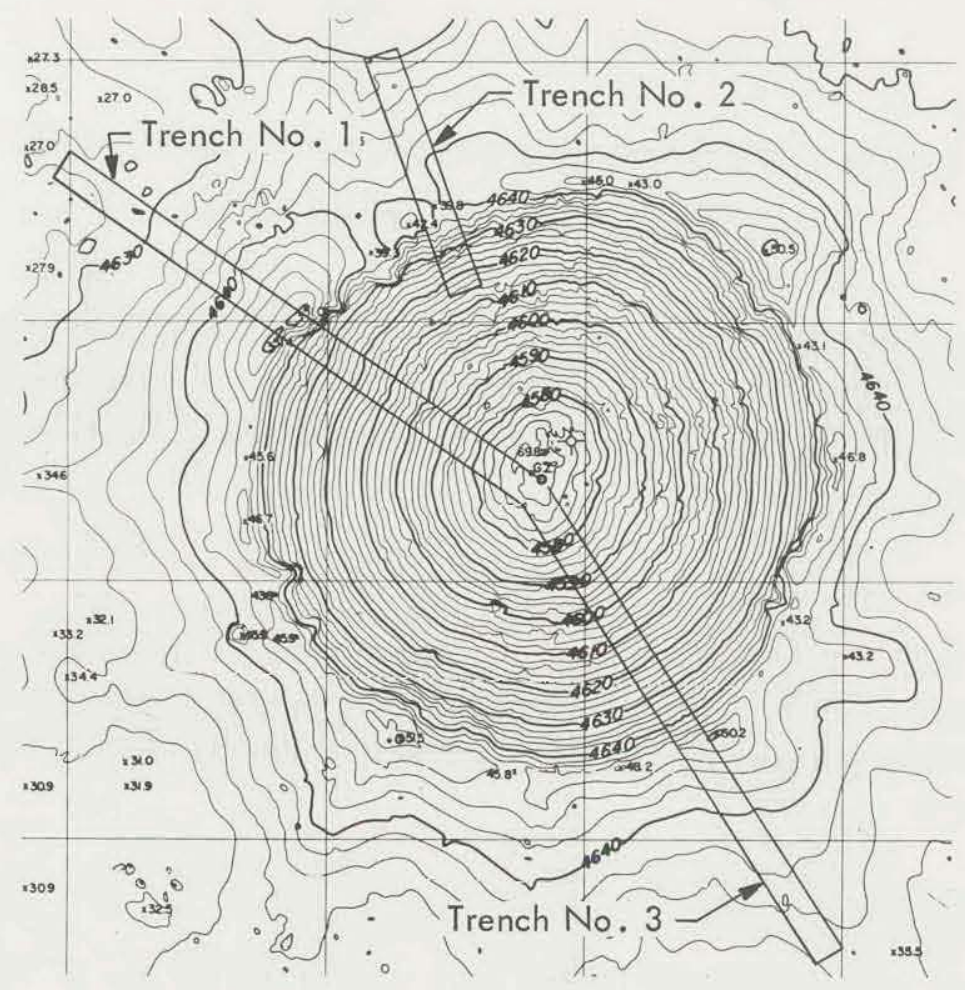

Figure 3.1 Location of trenches.

possible. A final aerial photograph and map were made at the completion of all excavation. Photographic stereoscopic pairs of the excavation phases, and corresponding topographic maps, are shown in Figures 3.2 through 3.7.

Concurrent with the excavation, screening of selected material was carried on to determine grain size distribution curves. The sequence of operations and the data obtained from each operation are shown in Table 3.1.

\subsection{EXCAVATION PROCEDURES}

Initial excavation through the crater lip consisted of removing the ejecta from above the upthrust ground surface which, in Trench No. 1, was marked with a colored grout strip laid down prior to the event. During excavation of the ejecta, special care was taken to stay above the upthrust original ground surface. After the ejecta had been removed and the volume determined, the trenches were deepened by excavating the upthrust ground to depths of several feet below the original ground elevation.

In excavating the trenches, digging proceeded from the outer edge of the lip and progressed towards SGZ. Excavation was stopped short of the apparent crater, leaving a plug at the end of each trench. This was done in order to avoid pushing any of the trench material into the crater which would have caused some error in the bulk density calculations. 


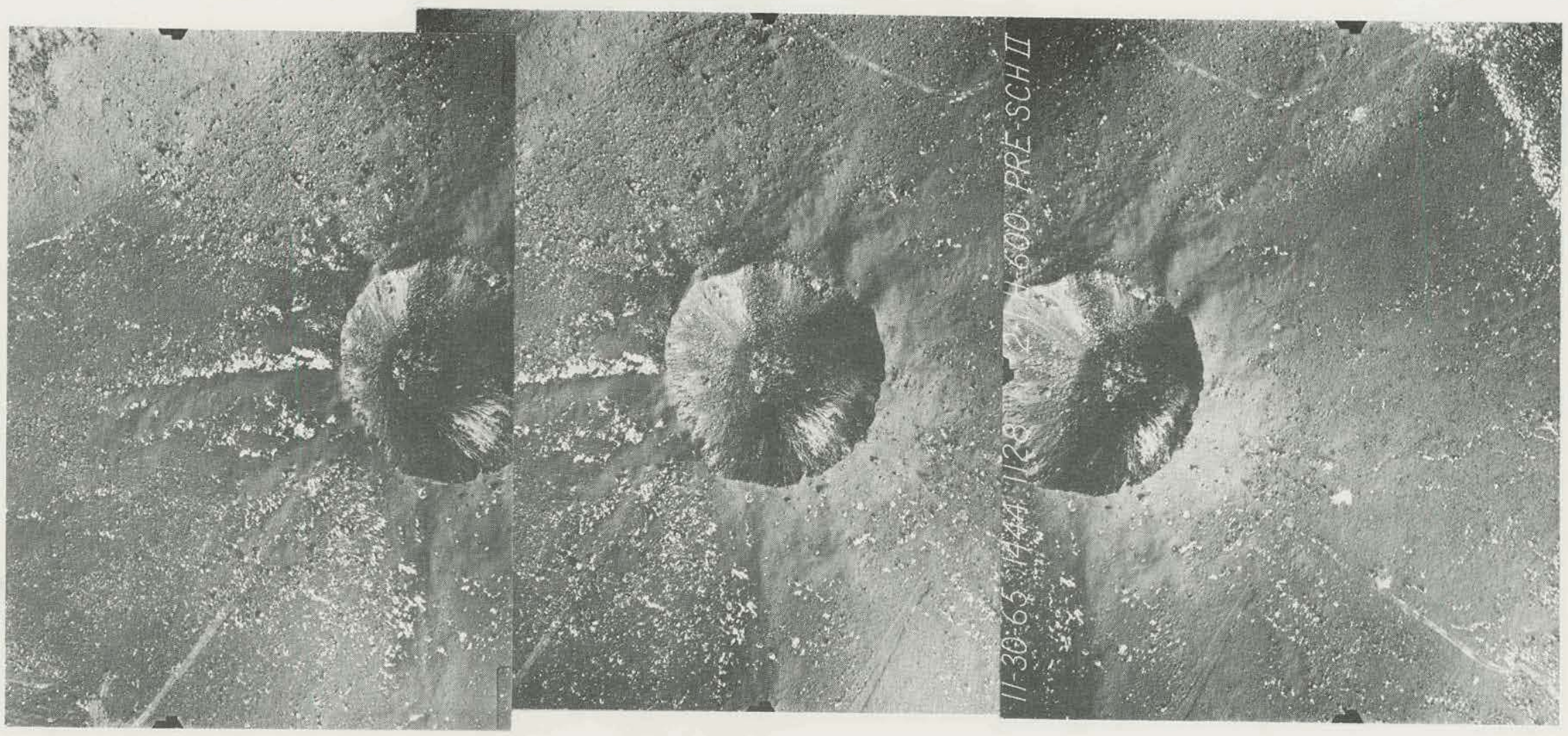

Figure 3.2 Postshot aerial photo prior to commencing excavations (photos grouped for stereoscopic viewing). 


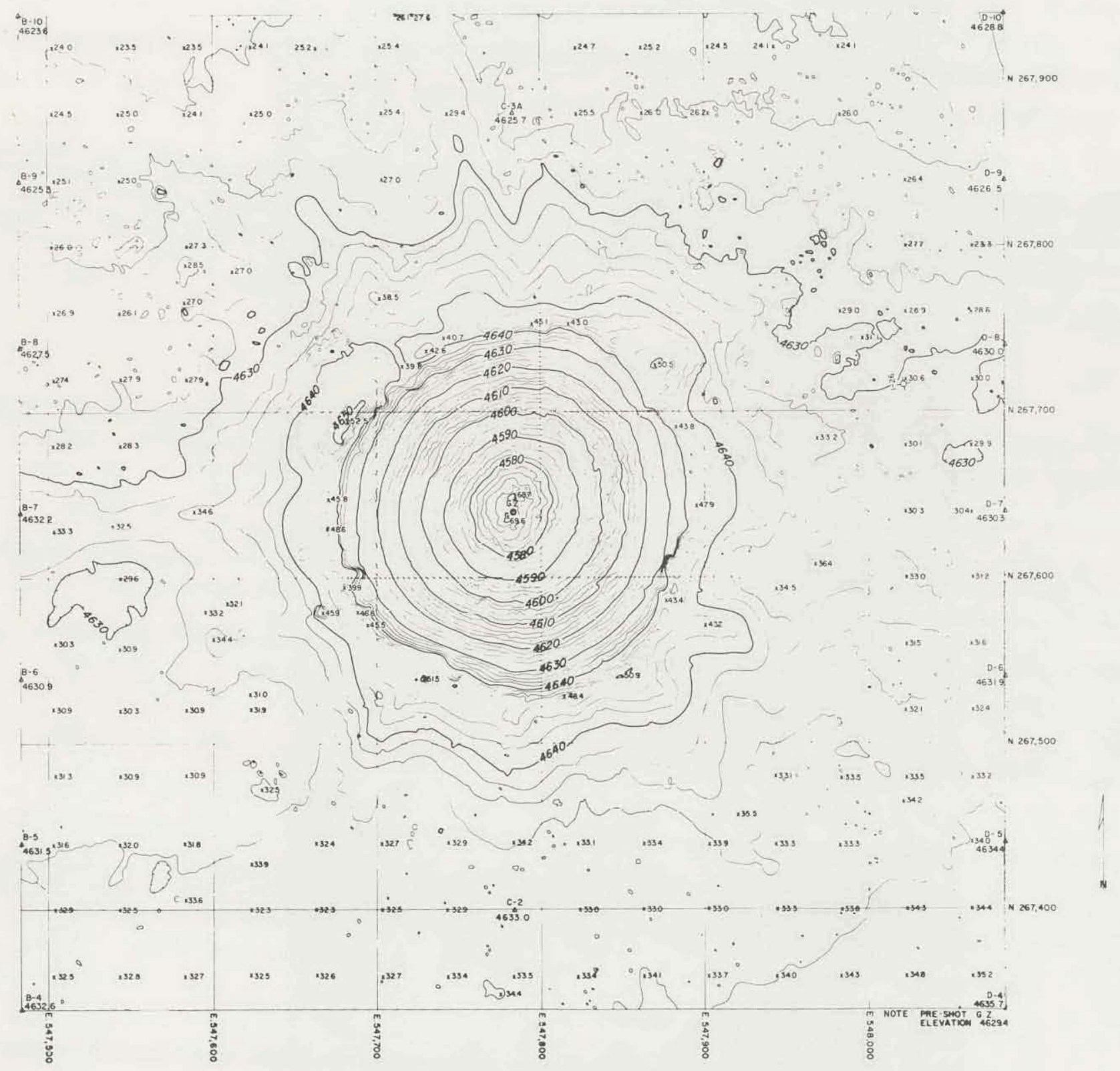

Figure 3.3 Postshot topographic map prior to commencing excavations. 


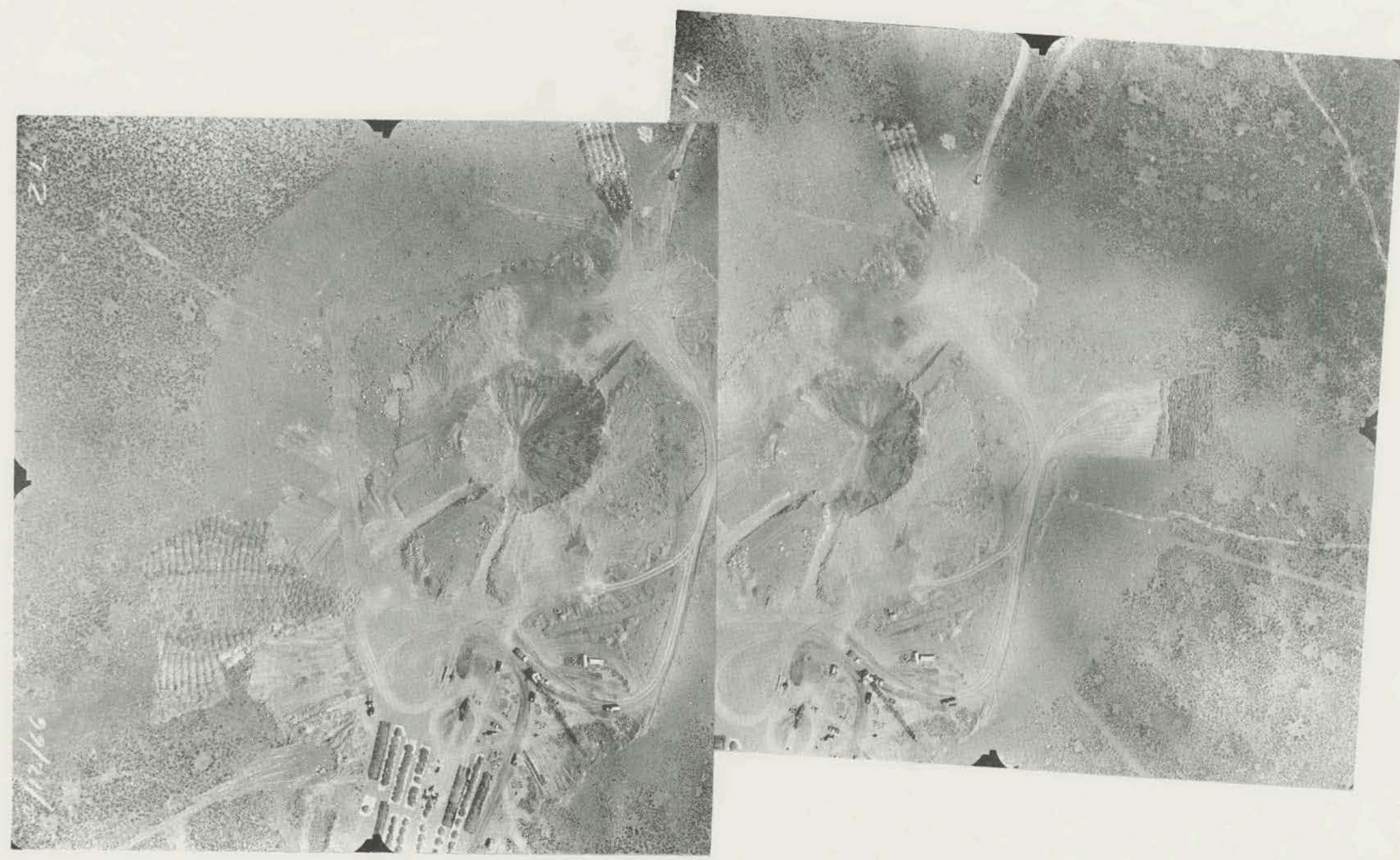

Figure 3.4 Aerial photo prior to excavation of fallback (photos paired for stereoscopic viewing). 


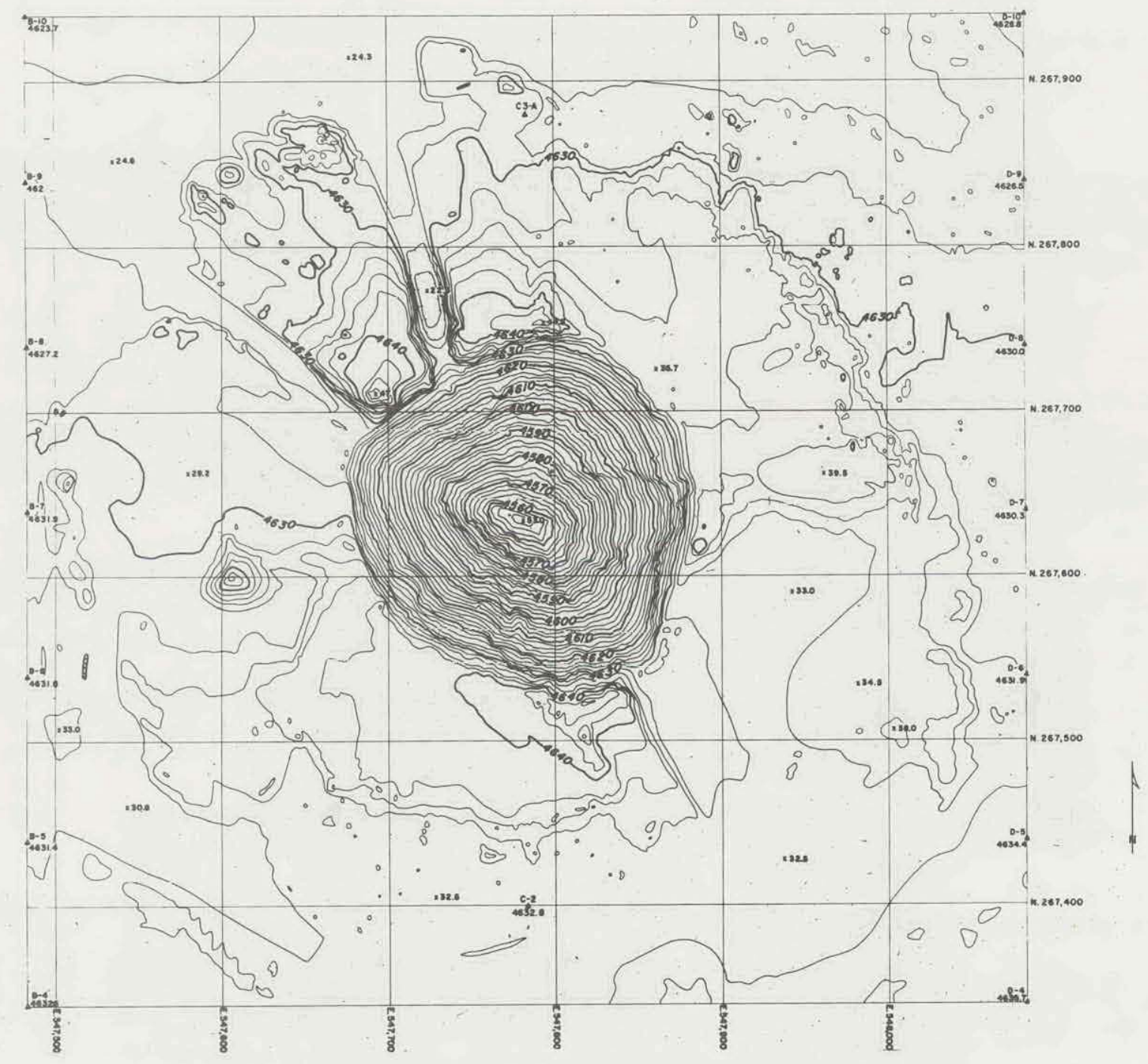

Figure 3.5 Topographic map prior to excavation of fallback. 


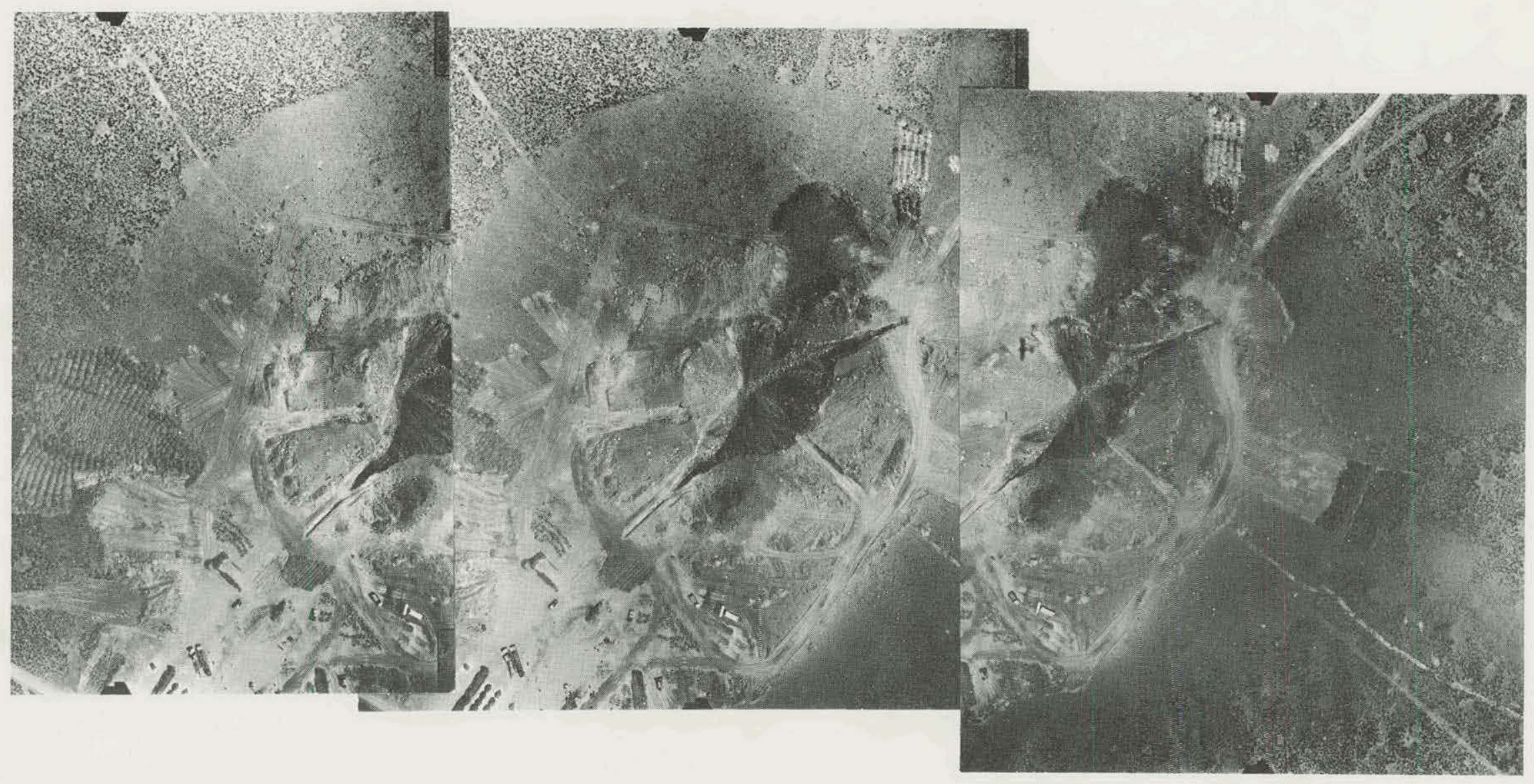

Figure 3.6 Aerial photo after completion of all excavation (photos grouped for stereoscopic viewing). 


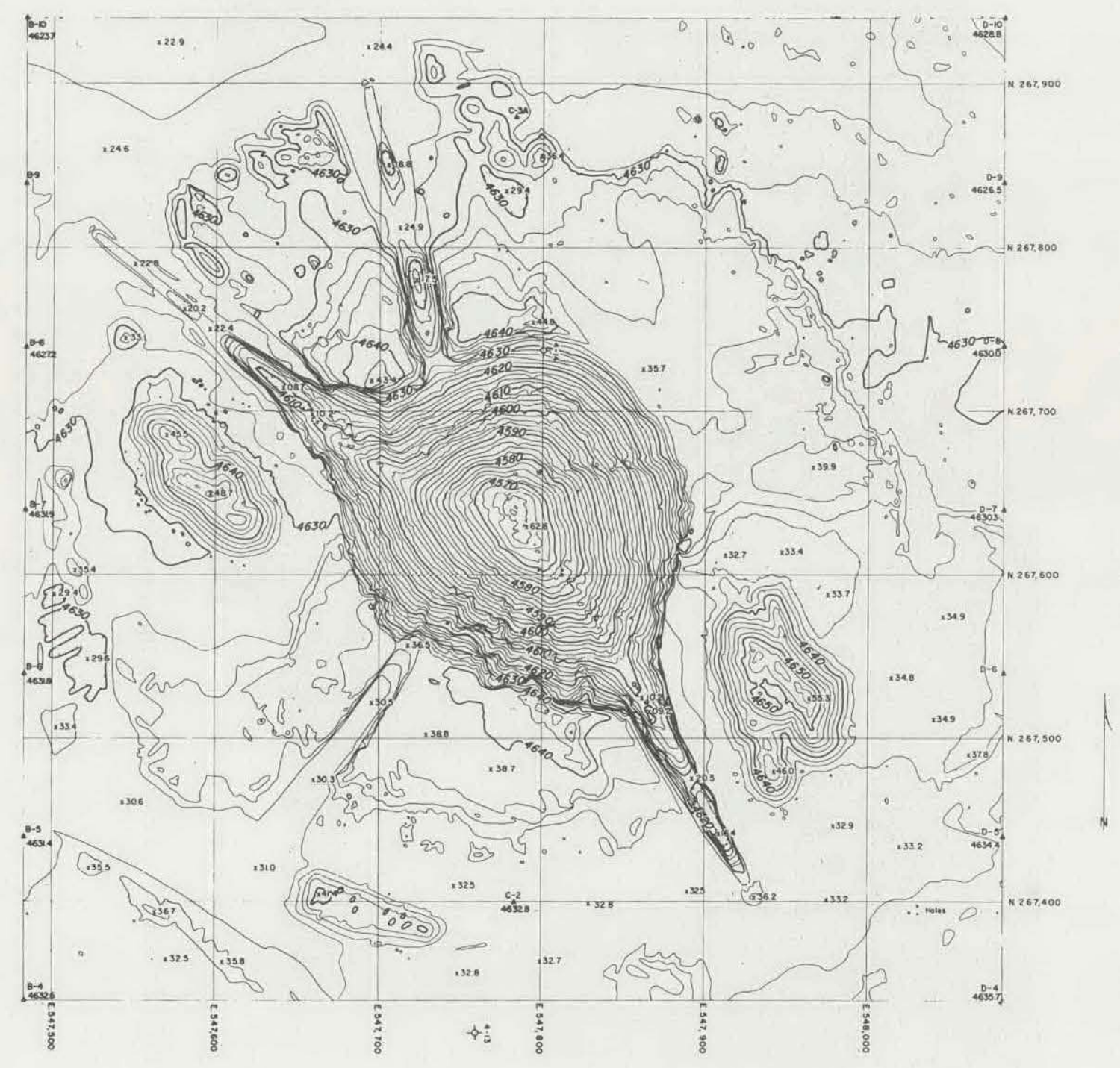

Figure 3.7 Topographic map after completion of all excavation. 
TABLE 3.1 POSTSHOT INVESTIGATIONS

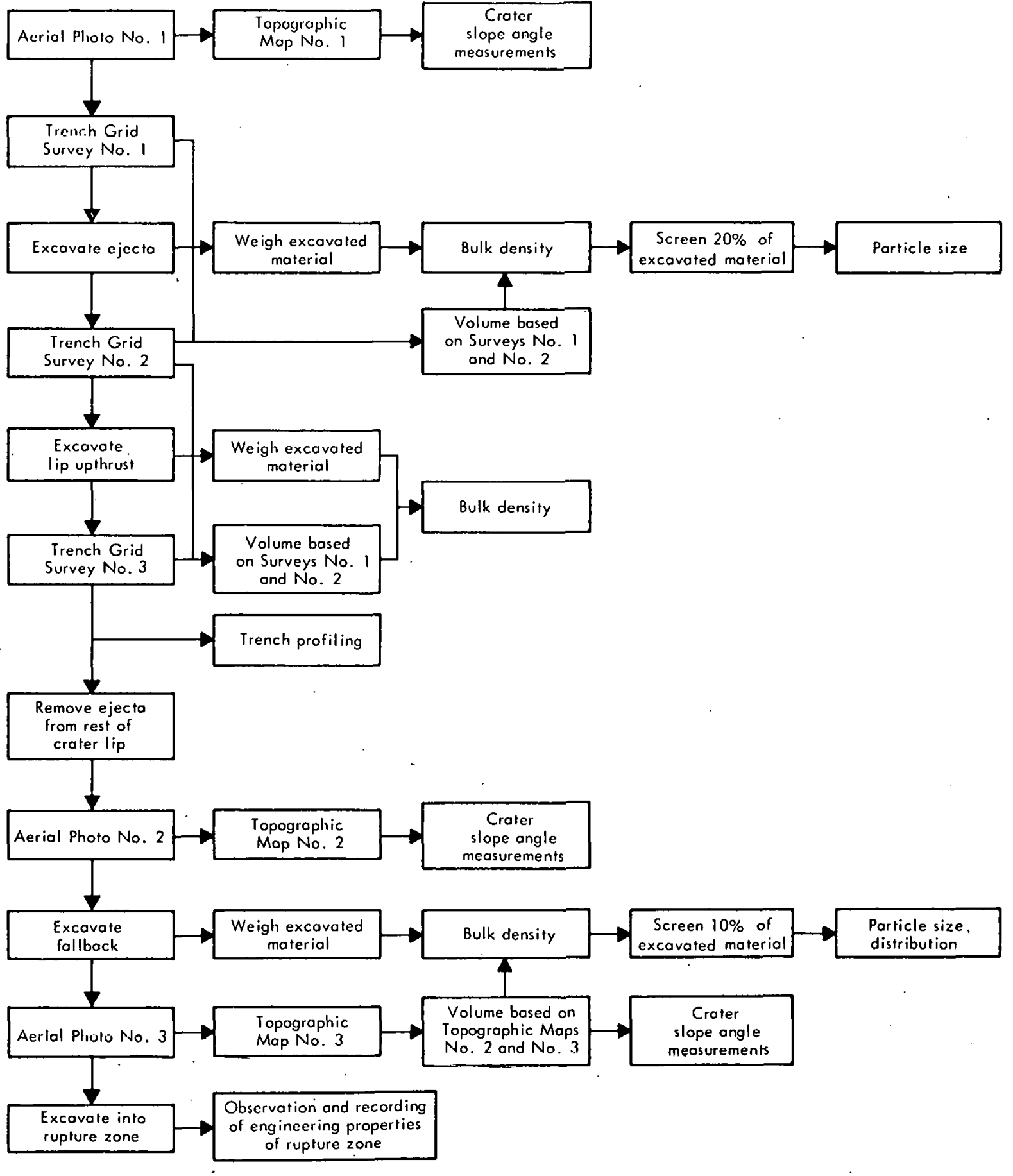


The fallback inside the crater was excavated with a dragline from the outer ends of the two trenches (No. 1 and No. 3). The crater excavation was started with the dragline crane set back about 10 feet from the apparent crater lip, and digging began about midway down the slope. When the upper part of the slope was removed back to the crane, the bottom of the crater was dug out as deep as possible, after which the crane was moved back a little farther and the process repeated. The excavated material was stockpiled alongside the crane and then for weighing, was loaded into trucks with an end loader.

\subsection{BULK DENSITIES}

The methods of handling the excavated material and making volume determinations for use in computing bulk densities were different for the fallback and the ejecta.

3.4.1 Weighing Procedures. In all cases the material excavated was loaded onto dump trucks which were then weighed on portable truck scales. Material from the trench excavation was loaded directly into the trucks as it was removed. The fallback material was stockpiled near the crane and then loaded into the trucks with the loader.

3.4.2 Volume Determinations. The volume of material removed from the trenches for weighing was determined from a ground survey run on a 3 -foot-square grid pattern. The grid survey was run before and after excavation of the ejecta. After excavation of the upthrust, profiles spaced at 10-foot intervals were run perpendicular to the trench centerline. These profiles were used to compute the volumc of upthrust material excavated.

The initial grid for each trench extended from approximately the lip crest in a direction away from SGZ for some distance, depending on the amount of ejecta. Each grid extended 45 feet on either side of the trench centerline. Subsequent grids were extended only a few stations beyond the limits of disturbance caused by excavation. These subsequent grids were also modificd to obtain elevations at major slope breaks which did not coincide with the preceding profile, such as at the toe of the slope bounding the trench. Figure 3.8 shows a typical profile for the various stages of trench excavation.

The volume of fallback material excavated from the crater was calculated from topographic maps made from aerial photographs. Maps of the crater, both pre- and post-excavation, were cross-sectioned in an east-west direction at 3-foot intervals. Since the cross sections were taken along the same line in both instances, the difference between the two represents the end area from which material was removed. A standard end area computational method was then used to determine the volume.

The topographic maps were drawn from the aerial photographs at a scale of 1 inch equals 20 feet and a contour interval of 2 feet. Accuracy of the contours with respect to elevation is $1 / 2$ contour interval or better. 


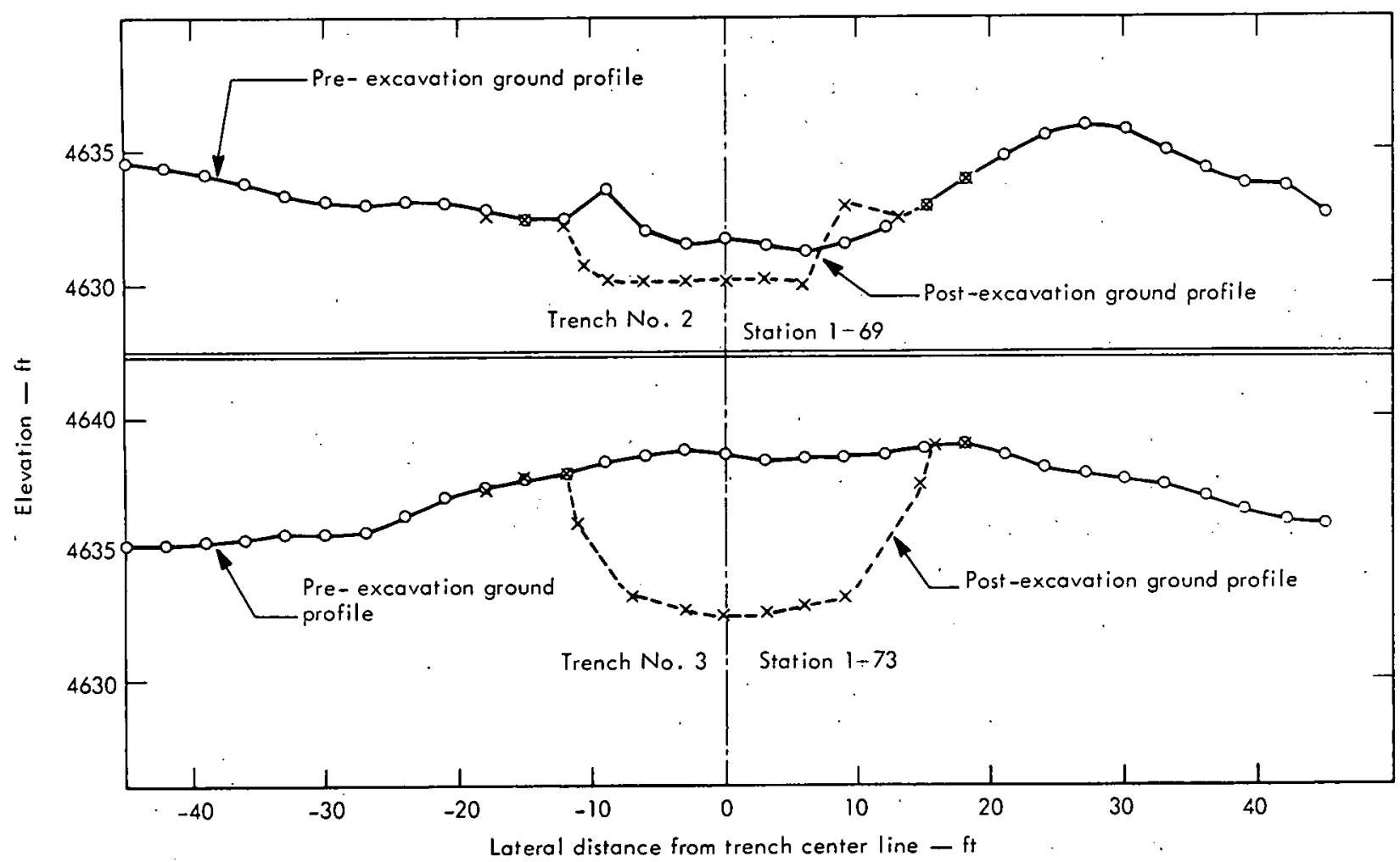

Figure 3.8 Typical cross sections for various stages of trench excavation.

\subsection{GRAIN SIZE DISTRIBUTION}

After the trucks were weighed for the bulk density determinations, they were either dumped in a general waste area or dumped in individual piles for screening to determine grain size distribution curves. Every fifth load from the trenches and every tenth load from the crater were saved for this purpose.

The material retained for screening was processed by manual and mechanical methods into the following sizes: No. $4,3 / 8,3 / 4,1-1 / 2,3,6$, and 12 inches, and 3 and 6 feet.

\subsection{TRENCH MAPPING}

Several methods were used to clean and mark the trench walls so that sketch maps and photographs could be obtained after completion of the trench excavations. The original ground surface was located, marked, and surveyed. The various zones of material, such as ejecta, uplift, soil, caliche, etc., were mapped and photographed. Reference points for sketching the separate elements of the exposed trench walls were provided by various grid methods. 


\section{CHAPTER 4}

POSTSHOT RESULTS AND DISCUSSION

\subsection{BULK DENSITY}

Measurements to determine the bulk density (bulking factor) of the ejecta, rupture zone, and fallback gave results as listed in Table 4.1. This table also includes results from prior investigations at other craters. The 143-pcf in-situ density used to compute the bulking factor is an average of the dry bulk densities of ten preshot samples taken above the depth of the explosive cavity.

As can be seen from the table, the bulk density for the ejecta and fallback were very similar except for Trench No. 1. This same close relationship between fallback and ejecta was observed at the Pre-Schooner Delta crater. Excluding this single low value in Trench No. 1, the average for the remaining three measurements is 103.8 pcf, which gives an average bulking factor of 1.38 .

The relatively wide range of bulk densities obtained from the rupture zone (97.6 to $112.9 \mathrm{pcf}$ ) is probably due to the varying amounts of overburden included from trench to trench and to the differences in bulking that can be inferred from the amount of uplift. As can be seen from the trench profiles, the maximum uplift and overburden occurred in Trench No. 1 which also had the lowest rupture zone bulk density. The maximum rupture zone bulk density occurred in Trench No. 3 which had the least amount of overburden and uplift.

\subsection{GRAIN SIZE DISTRIBUTION}

Approximately 20 percent of the material excavated from the trenches and 10 percent of the material excavated from the crater were retained and mechanically screened to make grain size distribution determinations. In an effort to obtain a representative sample of the excavated material, every fifth load was arbitrarily retained from the trenches and every tenth load from the crater. To increase further the random sample nature of this selection method, every other load saved from each individual trench was combined into a single pile and screened separately from the remaining material for that trench. For example, if loads numbered 1, 6, 11, 16, 21, etc., were saved from a trench, then loads $1,11,21$, etc., were screened as one group while loads 6, 16, etc., were screened as a second group. Grain size distribution curves are shown in Figures 4.1 through 4.3. The two different groups are shown as SP1 and SP2. In addition to this division of material, group SP1 from Trench No. 3 was further divided into SP1A and SP1B. 
TABLE 4.1 SUMMARY OF BULK DENSITIES

\begin{tabular}{|c|c|c|c|c|c|}
\hline & & $\begin{array}{c}\text { Volume of } \\
\text { Material } \\
\text { Excavated }\end{array}$ & $\begin{array}{c}\text { Weight of } \\
\text { Material } \\
\text { Excavated }\end{array}$ & $\begin{array}{l}\text { Bulk } \\
\text { Density }\end{array}$ & $\begin{array}{l}\text { Bulking } \\
\text { Factorb }\end{array}$ \\
\hline & & $\mathrm{ft}$ & $1 \mathrm{~b}$ & $p c f$ & \\
\hline \multicolumn{6}{|l|}{ Pre-Schooner II } \\
\hline \multirow[t]{2}{*}{ Trench No. 1} & Ejecta & 6,874 & 636,520 & 93.1 & 1.54 \\
\hline & Rupture Zone & 10,346 & 980,570 & 97.6 & 1.47 \\
\hline \multirow[t]{2}{*}{ Trench No. 2} & Ejecta & 6,764 & 694,070 & 102.5 & 1.40 \\
\hline & Rupture Zone & 8,139 & 918,590 & 112.9 & 1.27 \\
\hline \multirow[t]{2}{*}{ Trench No. 3} & Ejecta & 11,204 & $1,172,945$ & 104.2 & 1.37 \\
\hline & Rupture Zone & 10,008 & $1,047,195$ & 104.7 & 1.37 \\
\hline $\begin{array}{l}\text { Fallback Inside } \\
\text { Crater }\end{array}$ & & 214,186 & $22,430,023$ & 107.7 & 1.37 \\
\hline \multicolumn{6}{|c|}{ Previous Cratering Experiments } \\
\hline \multicolumn{5}{|l|}{ Pre-Schooner I } & 1.65 \\
\hline Dugout ${ }^{b}$ & & 29,462 & $3,509,070$ & 119 & 1.39 \\
\hline $\begin{array}{l}\text { Pre-Schooner I I } \\
\text { Trench No. } 1 \\
\text { Trench No. } 2 \\
\text { Crater }\end{array}$ & 1 ta & $\begin{array}{r}2,250 \\
5,311 \\
79,987\end{array}$ & $\begin{array}{r}217,840 \\
537,010 \\
7,864,870\end{array}$ & $\begin{array}{r}97 \\
101 \\
98\end{array}$ & $\begin{array}{l}1.70 \\
1.63 \\
1.68\end{array}$ \\
\hline
\end{tabular}

${ }^{a}$ Equation for bulking factor: $\frac{\text { in-situ density }}{\text { postshot density }}$ in-situ density $=143$ pcf.

${ }^{b}$ Row crater, five 20 -ton charges.

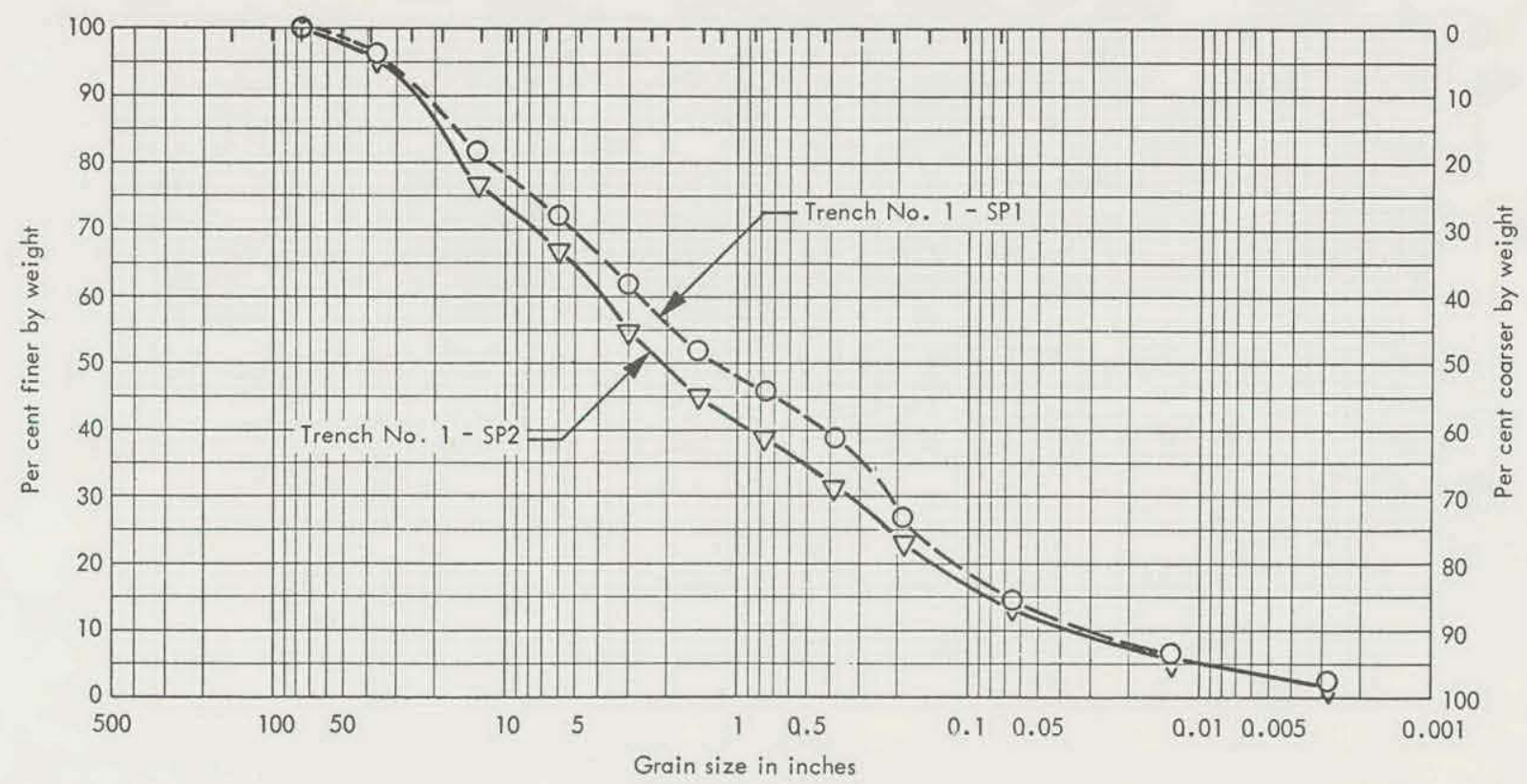

Figure 4.1 Grain size distribution curve for Trench No. 1. 


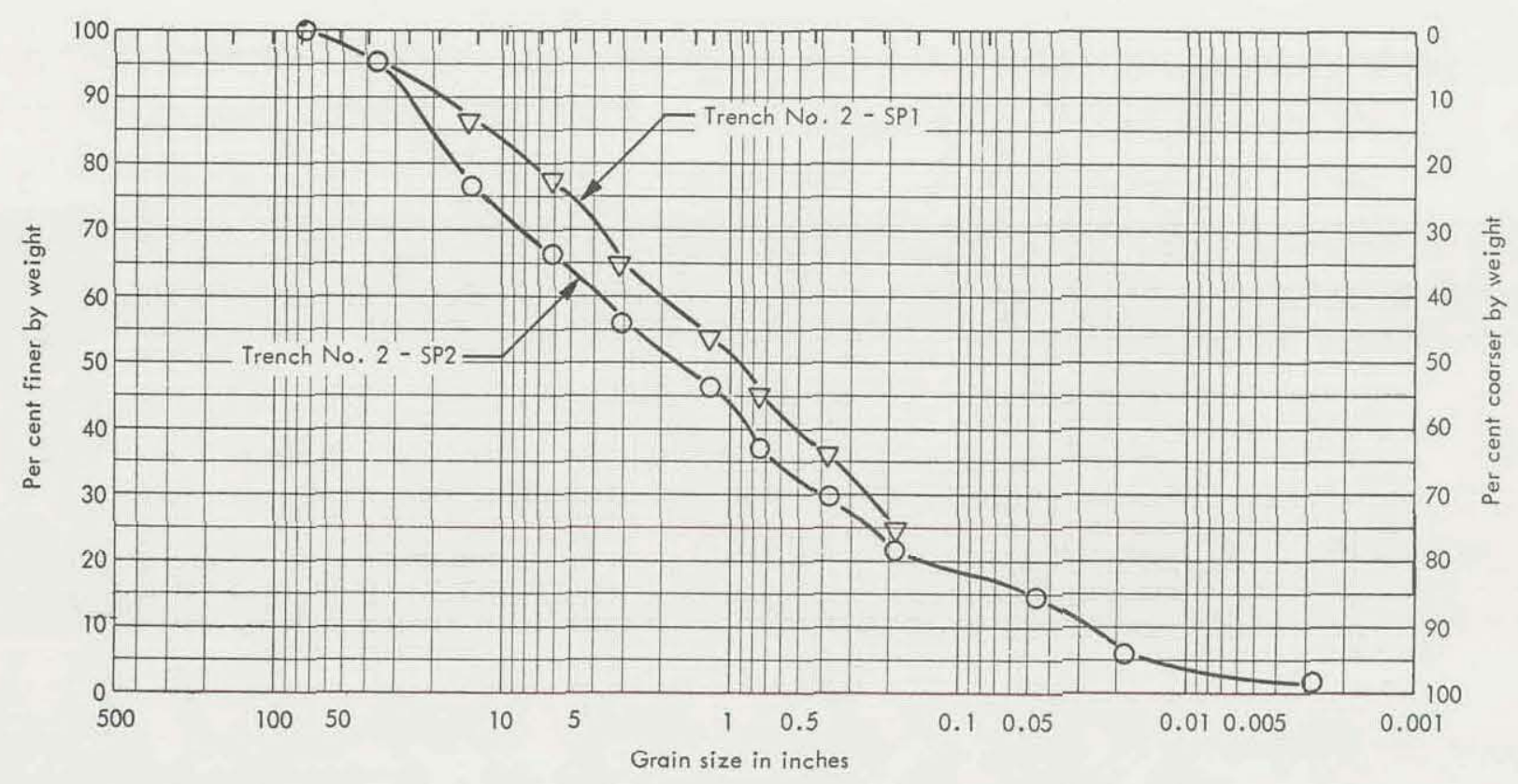

Figure 4.2 Grain size distribution curve for Trench No. 2.

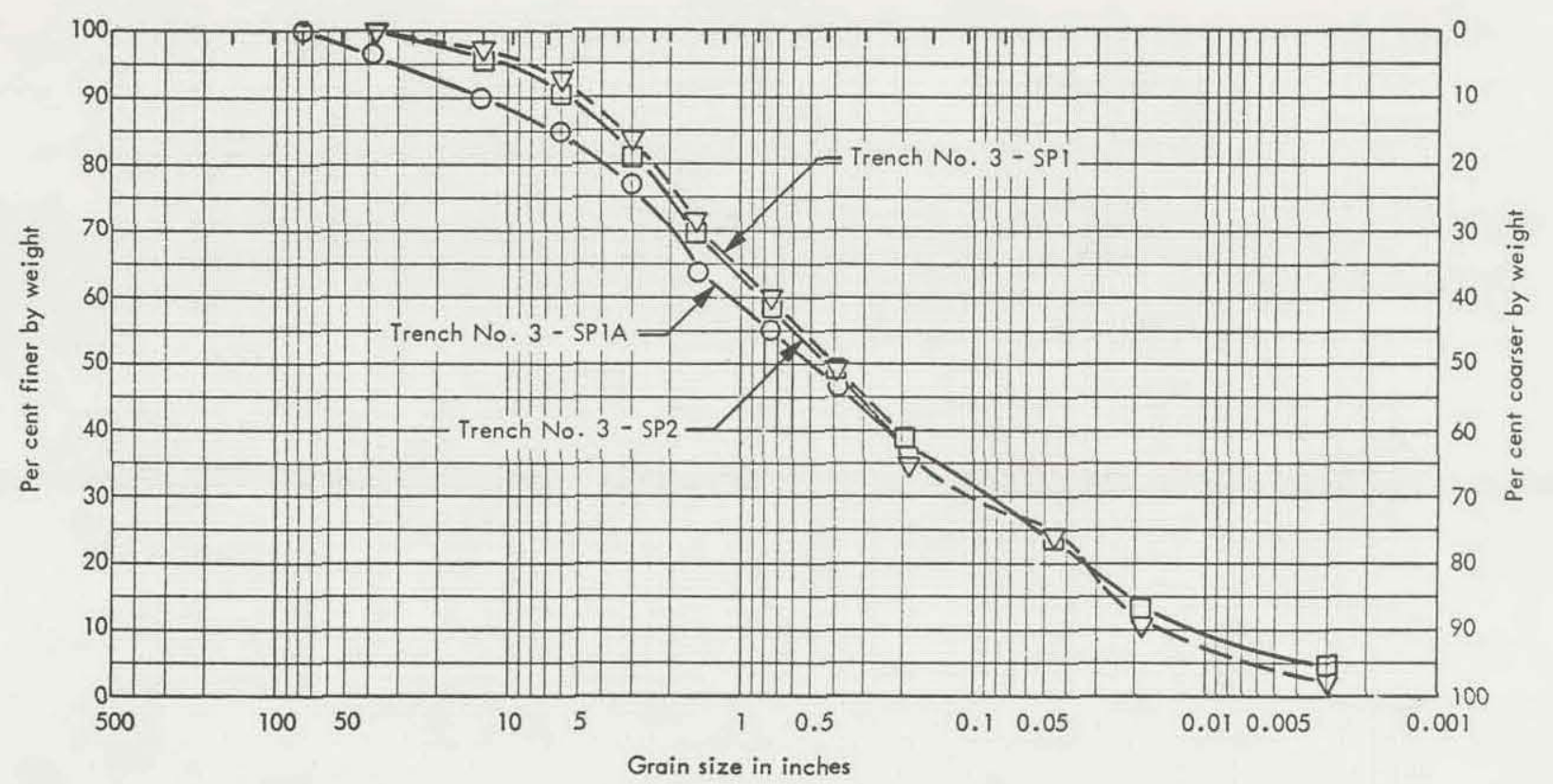

Figure 4.3 Grain size distribution curve for Trench No. 3. 


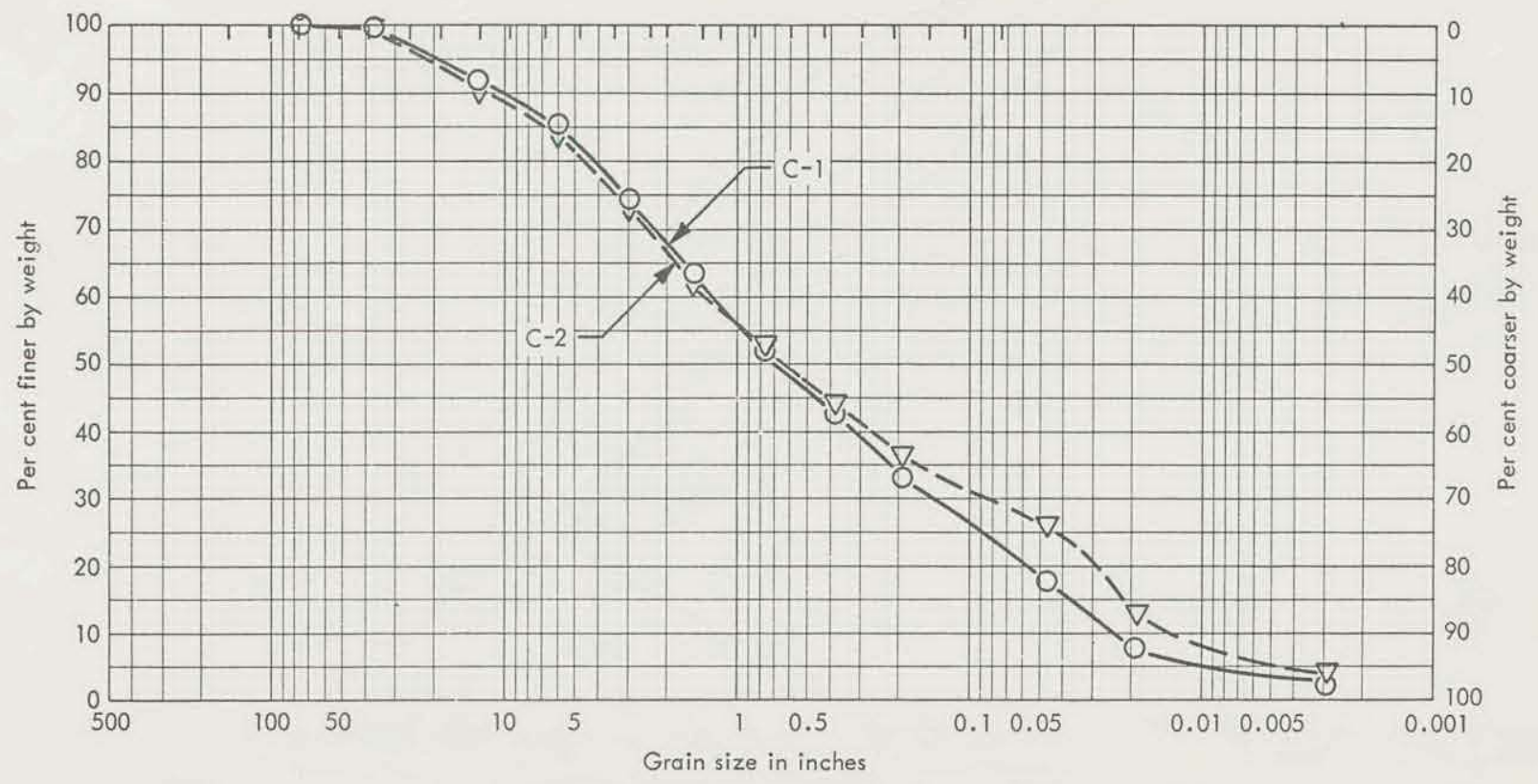

Figure 4.4 Grain size distribution curve for crater fallback.

The material from the crater was also screened in two separate groups, although the separation was made in a different manner. As explained in paragraph 3.3, excavation of the crater was accomplished by working the dragline from two locations on the crater lip (Trenches No. 1 and No. 3). The loads saved from each of these locations were screened as a separate group. The two screening analyses are shown as $\mathrm{C}-1$ and $\mathrm{C}-2$ in Figure 4.4 .

The distribution curves, show that there is fairly good agreement between curves SP1 and SP2 for each trench. The maximum variation occurred in Trench No. 2 in which the SP2 material is as much as 10 percent coarser than the SP1.

The combined curves from Figures 4.1 through 4.4 for the trenches and crater are shown in Figure 4.5 as a band illustrating the grain size distribution range. Also plotted in this figure are predicted size distribution curves for the vitrophyre and felsite constructed from preshot subsurface information (Reference 13). Because of the distinctly different fracturing characteristics of these two rock types and the predicted differences in grain size distribution, an effort was made to determine what percentage of each rock type was represented in the plus 6-inch size material. The data are shown in Table 4.2 as the percentage of each rock type in the size classifications 6 to 12 , 12 to 36 , and greater than 36 inches. Data from Trench No. 1 are missing because the material was mistakenly discarded before the percentages were determined. Table 4.3 gives a rough estimation of the relative amounts of the different rock types in the vicinity of each of the trenches prior to the detonation. There is no apparent agreement between the percentages of the different rock types in the ejecta from each trench and the percentages given in Table 4.3 . 

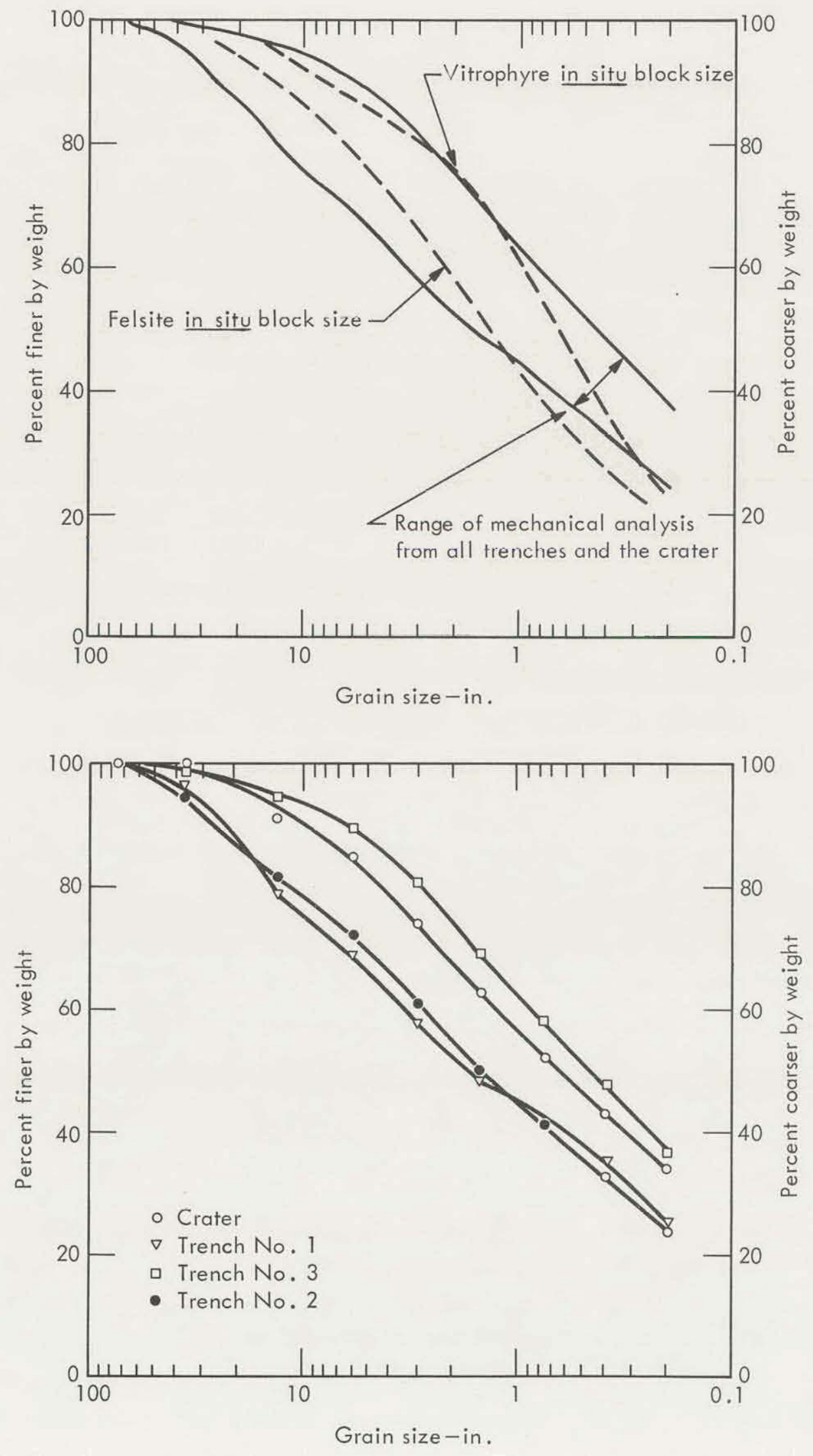

Figure 4.5 Comparison of predicted block size for two major materials, and postshot fallback and ejecta mechanical analyses. 
TABLE 4.2 DISTRIBUTION OF ROCK TYPE IN LIP EJECTA WITH RESPECT TO SIZE

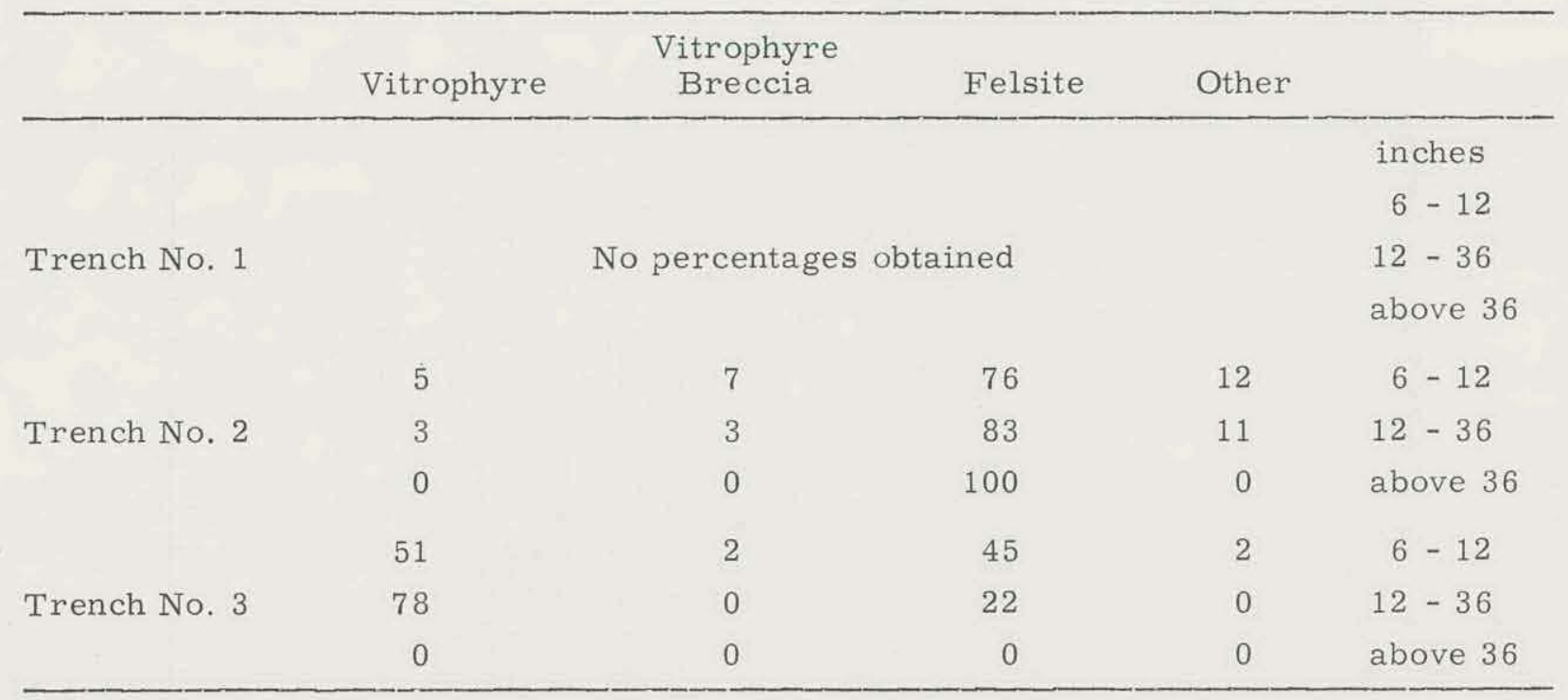

TABLE 4.3 PRESHOT PERCENTAGE DISTRIBUTION OF ROCK TYPES WITHIN CRATER AREA

\begin{tabular}{|c|c|c|c|}
\hline & Vitrophyre & $\begin{array}{c}\text { Vitrophyre } \\
\text { Breccia }\end{array}$ & Felsite \\
\hline & $\%$ & $\%$ & $\%$ \\
\hline $\begin{array}{l}\text { Entire } \\
\text { Area }\end{array}$ & 25 & 33 & 42 \\
\hline $\begin{array}{c}\text { Northwest } \\
\text { Zone }\end{array}$ & 0 & 41 & 59 \\
\hline $\begin{array}{c}\text { Northeast } \\
\text { Zone }\end{array}$ & 52 & 22 & 26 \\
\hline South Zone & 22 & 38 & 40 \\
\hline
\end{tabular}

\subsection{TRENCH MAPPING}

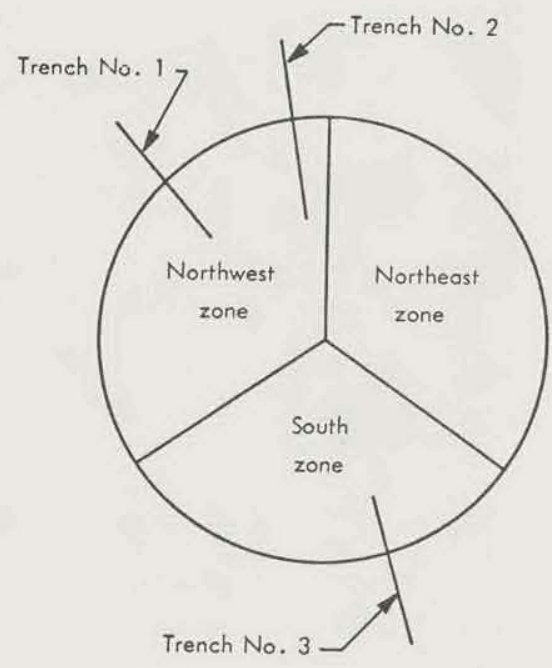

After the trenches were excavated, one wall of each trench was examined and mapped to delineate the true crater boundary and amount of uplift. The results of this mapping are shown in Figures 4.6 through 4.9 for Trenches No. 1, and No. 3. The true crater radius and amount of uplift are listed in Table 4.4.

From an examination of the trench profiles, it can be seen that in all three trenches the soil and caliche have been removed from above the uplifted bedrock for a distance of 8 to 24 feet back from the true crater zone. This condition is probably the result of surface spalling. In Trench No. 1 there has also been overthrusting of wedges of material which, prior to the detonation, constituted the ground surface closer to SGZ. 

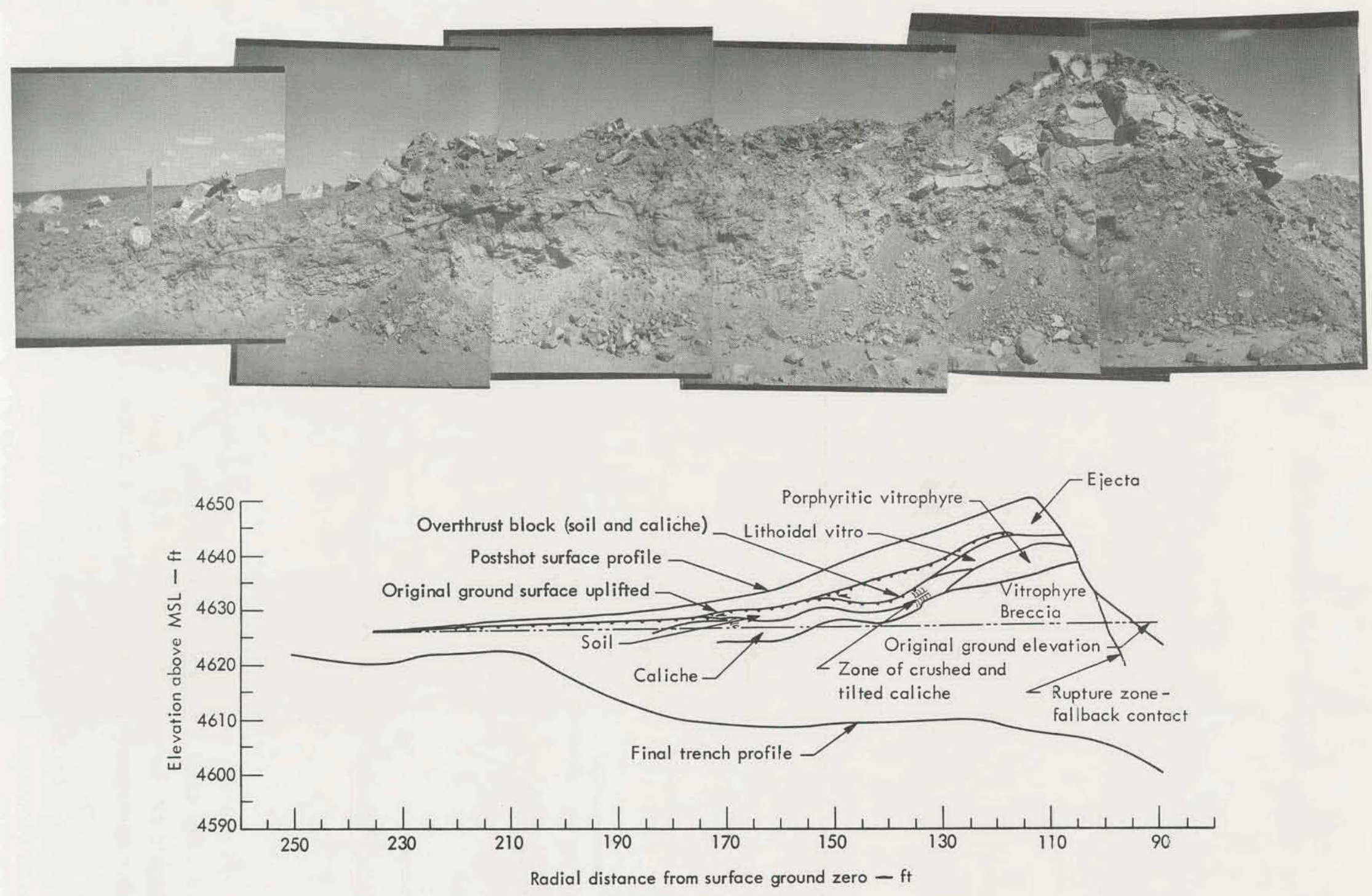

Figure 4.6 Ground profiles from Trench No. 1. 

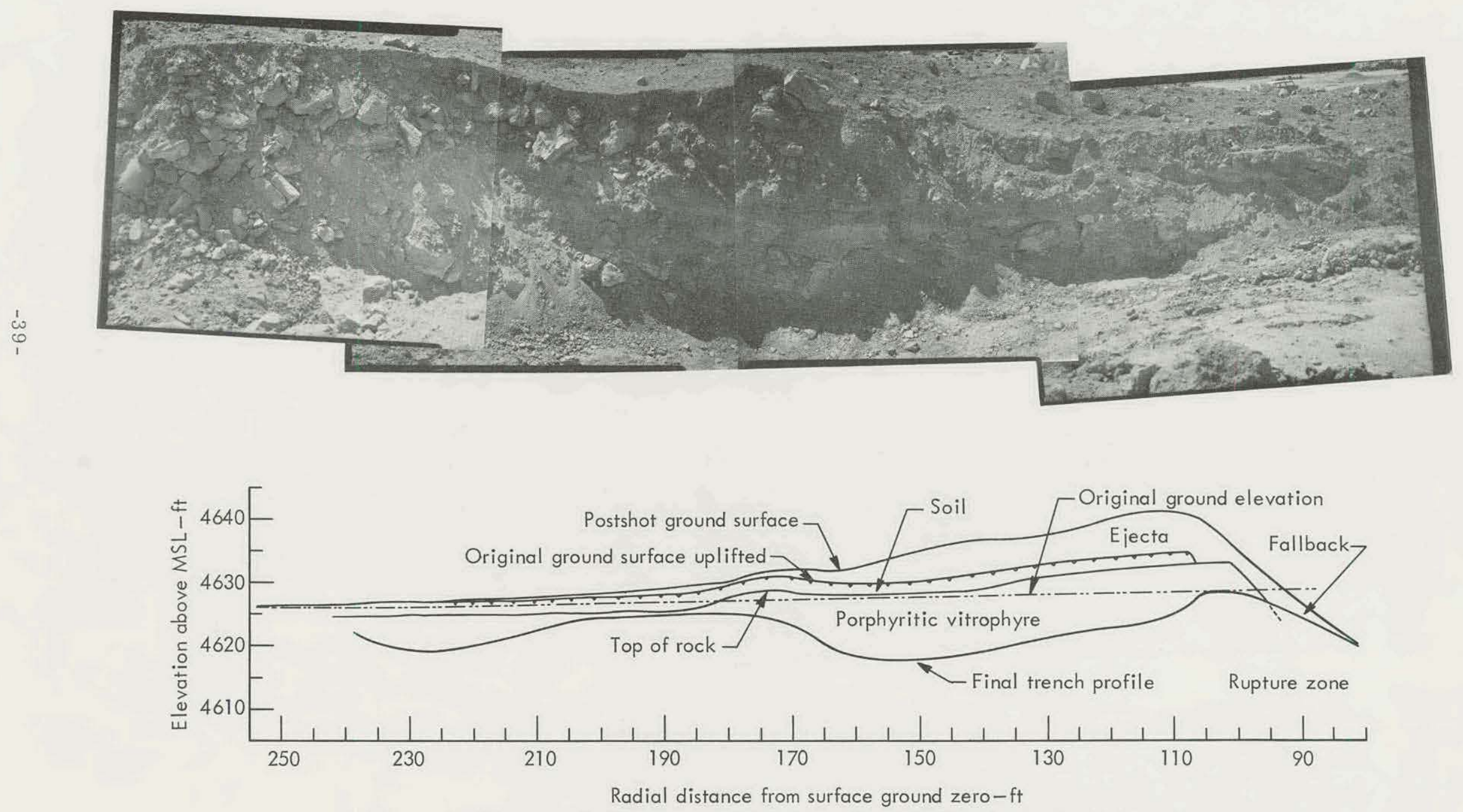

Figure 4.7 Ground profiles from Trench No. 2, west wall. 

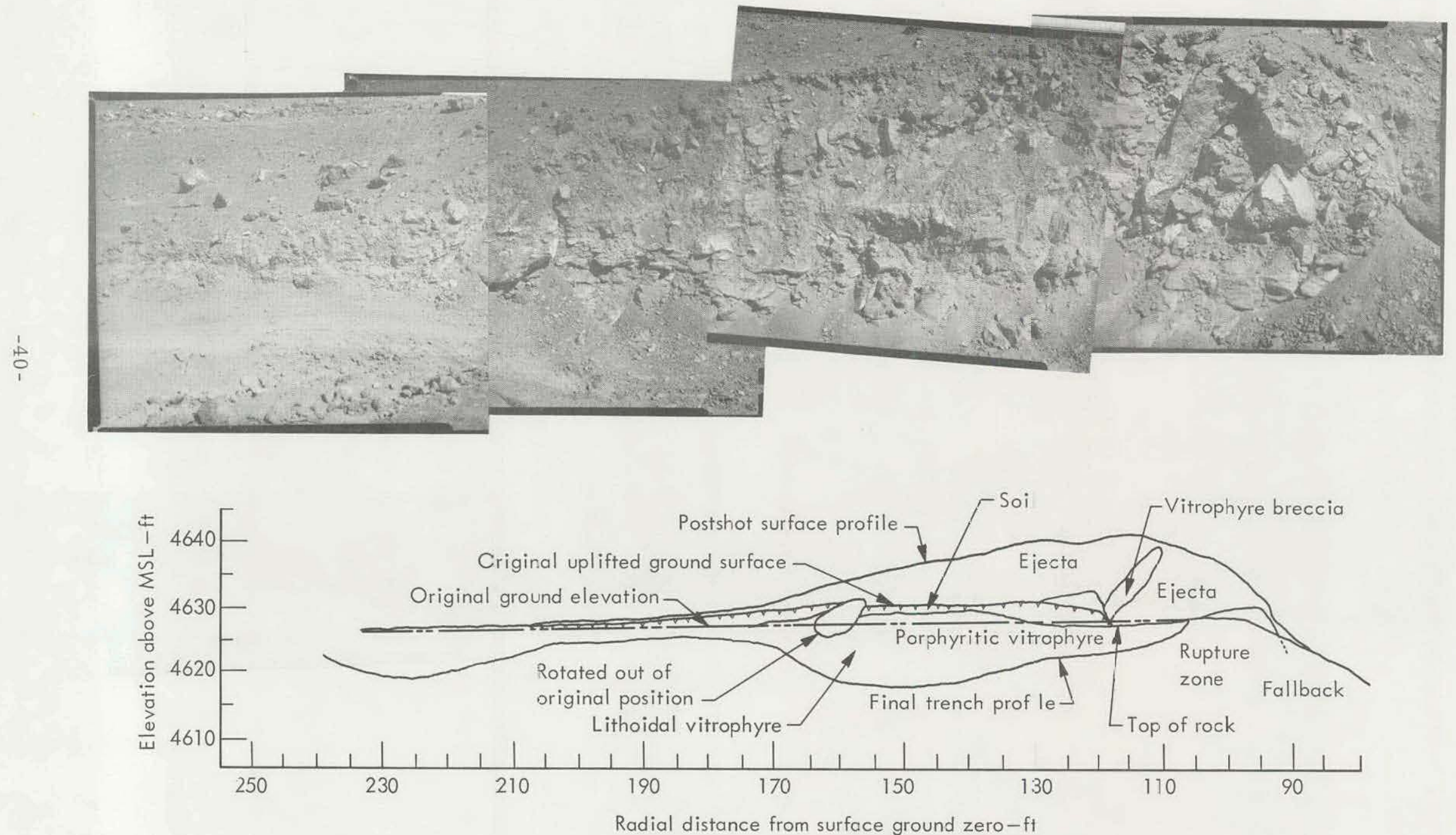

Figure 4.8 Ground profiles from Trench No. 2, east wall. 

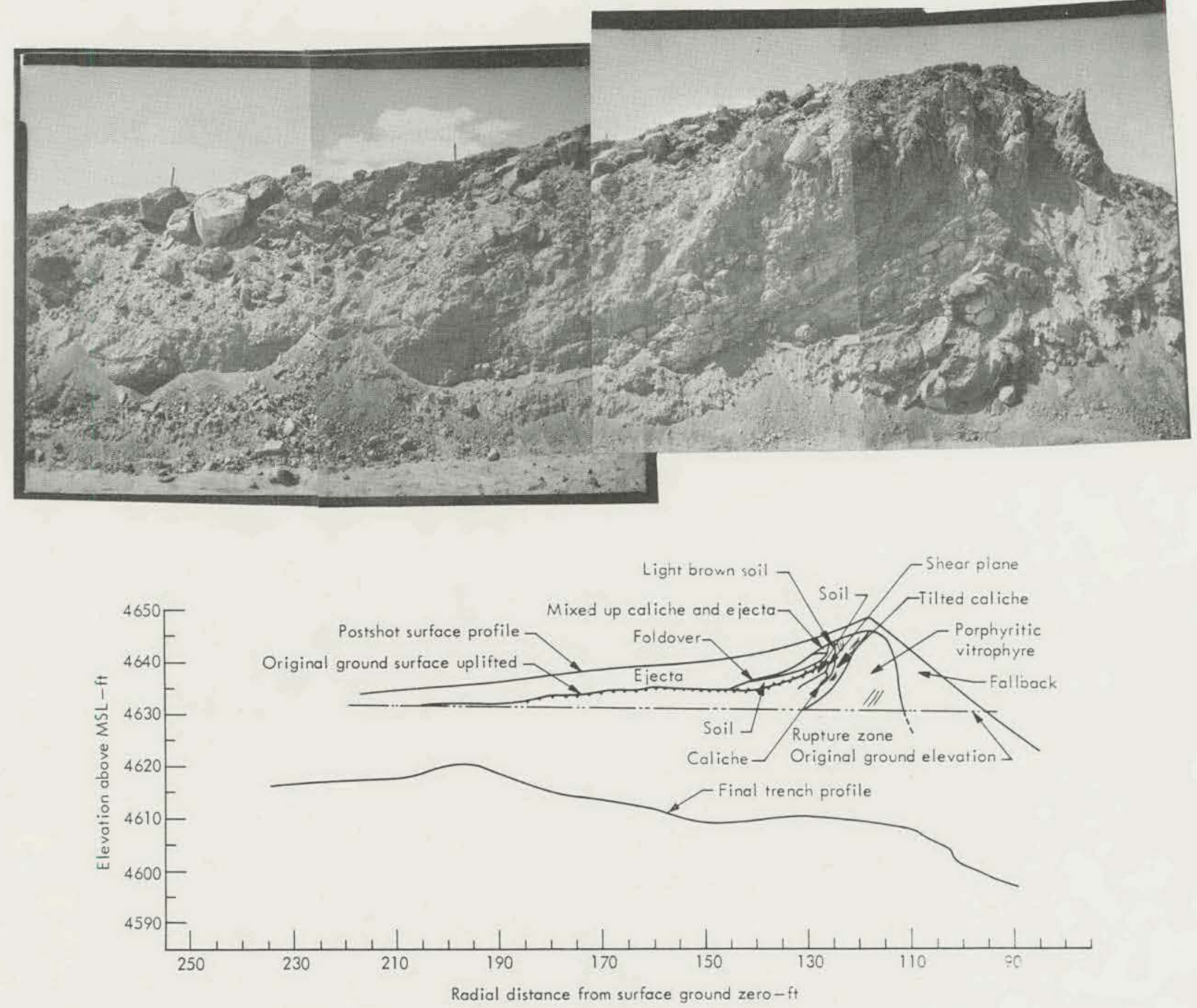

Figure 4.9 Ground profiles from Trench No. 3. 


\begin{tabular}{ccrc}
\hline & Bearing from & True Crater Radius & Uplift \\
\hline & SGZ & feet & feet \\
1 & & 100 & 17 \\
2 & N $56^{\circ}$ W & 96 & 7 \\
2 & N $18^{\circ}$ W, west wall & 94 & 4 \\
3 & N $18^{\circ}$ W, east wall & 111 & $15-1 / 2$ \\
\hline
\end{tabular}

Overthrusting is also evident in Trench No. 2; however, in this case it is considerably farther back from the true crater boundary zone (roughly 160 feet from SGZ) and is manifested as the rotation of a large boulder and variation of the ground surface on either side of the boulder. No visible thrusting occurred in Trench No. 3, but the tilted and curved nature of the caliche at the true crater boundary suggests an overturning of at least the soil and caliche zones. These overturned materials are also evident slightly farther back in the trench profiles.

All the trenches were closely examined below the original ground surface in an attempt to determine the nature and extent of blast-induced fracturing. Although some fracturing which could be attributed to the detonation was observed, the nature of the medium is such that no quantitative analysis could be made.

\subsection{GENERAL OBSERVATIONS}

Prior to and during excavation of the Pre-Schooner II crater, some general observations were made concerning slope adjustments and conditions.

\subsubsection{Slope Adjustments Prior to Postshot Excavations. Examination of aerial} photographs taken at intervals after the detonation indicates that the slopes did not change appreciably with time. Shot day was 30 September 1965; photographs were taken on 1 October 1965, 30 November 1965, and 17 March 1966. The most visibly noticeable change which occurred was the accumulation of the coarser material in the bottom of the crater. Since no visible failures in the fallback slopes occurred during this period, it is assumed that the slopes formed by the detonation constituted the "angle of deposition" (Reference 14) for the material. The minor slope adjustments which did occur were the result of weather elements, such as wind, rain, and snow. Some of the surficial segregation of particle sizes may have occurred during these minor adjustments.

When excavation inside the crater was started, it was evident that coarse layering of grain sizes existed in the upper 4 to 5 feet of fallback, particularly in the bottom of the crater. This layering is illustrated schematically in Figure 4.10. 


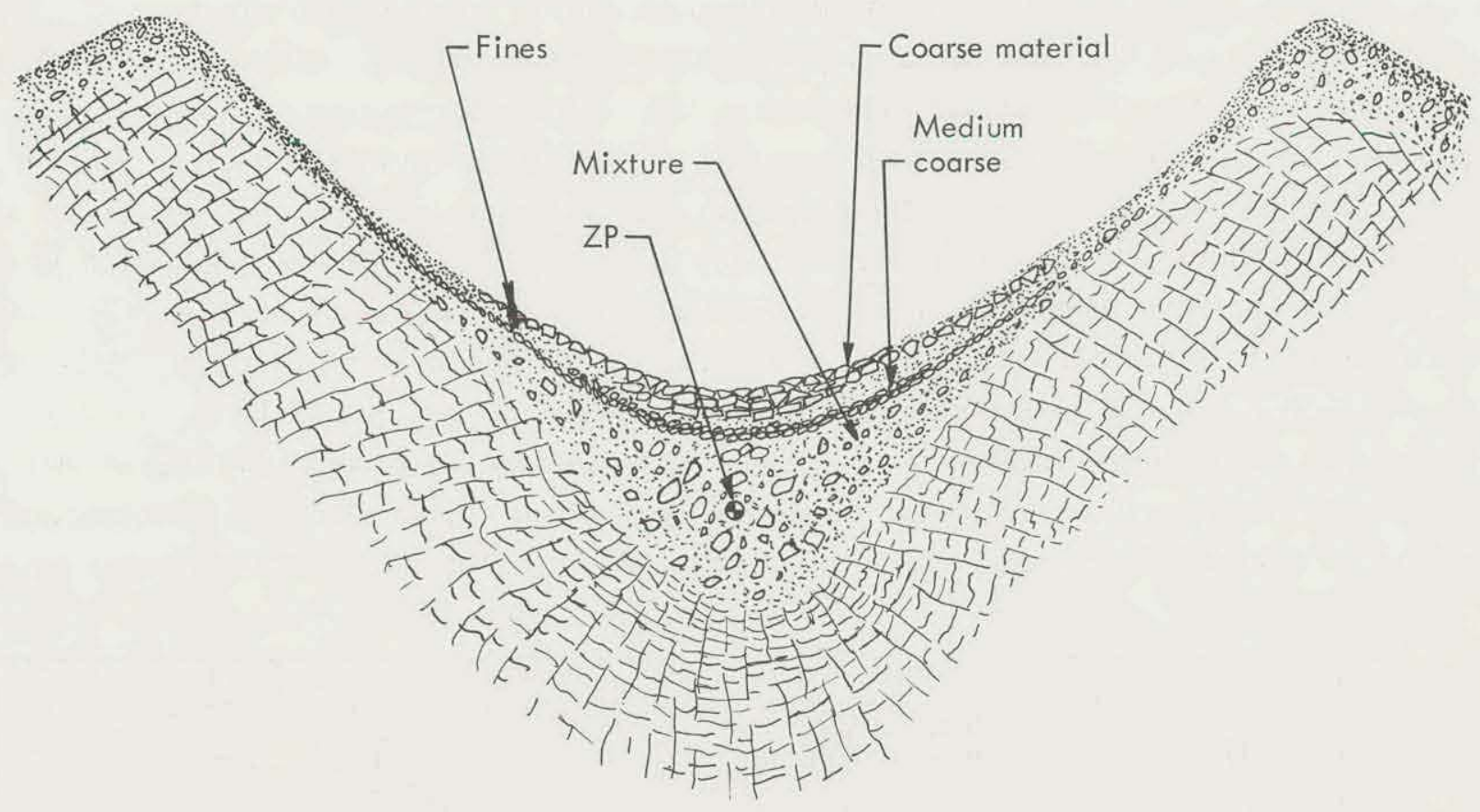

Figure 4.10 Diagramatic segregation of block sizes in crater.

4.4.2 Slope Adjustments During Postshot Excavations. During excavation of the trenches as discussed in paragraph 3.3, the crater slopes were continually failing or sloughing. The fallback was excavated primarily along two radials from SGZ. By excavating in this manner, the slopes which were initially standing at their angle of deposition were gradually undercut (i.e., the slope toe was continuously cut away). When a vertical face, ranging in height from 2 to 6 feet at the slope toe was developed,

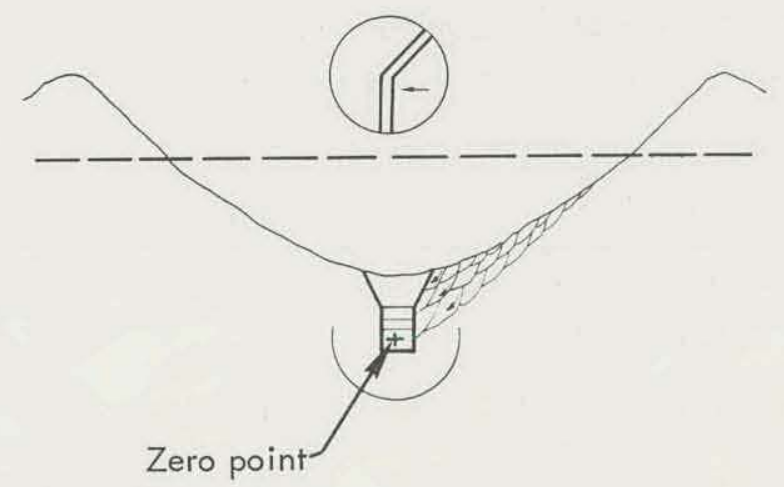

Figure 4.11 Diagramatic illustration of mode of failure during fallback excavation. the slope would begin a progressive surficial failure which eventually reached the top of the crater. This mode of failure is illustrated in Figure 4.11. The upslope face of these failures always remained nearly vertical. The time it took for one of these failures to progress to the crater lip varied from several hours to several days. The amount of material involved was always small; however, there were generally several failures of this type occurring at any one time.

4.4.3 Slope Angles. The angle of repose for a cohesionless material is the maximum possible inclination of a slope of that material. The angle of deposition has been defined as the inclination of a slope formed by the deposition of cohesionless material 
and depends both on the character of the material and the mode of deposition (Reference 14). For all practical purposes, the fallback material at Pre-Schooner II can be considered cohesionless. Therefore, the crater slope angles, prior to any postshot investigations, represented the angle of deposition for this material. This average angle was 37 degrees. The slopes in part of the crater were then steepened by undercutting the toe of the slope to an average inclination (angle of repose) of 42 degrees. After a short period of readjusting (approximately 1 week), the slope stabilized at 38 degrees. Figure 4.12 illustrates the various stages of slope stabilization. A later aerial photograph and topographic map obtained in June 1967 (Figures 4.13 and 4.14) shows that the undercut slopes which readjusted to 38 degrees were remaining at that angle. In other parts of the crater where the slopes were much steeper, readjustment to flatter slopes is occurring. Long term slope adjustments will be examined periodically.

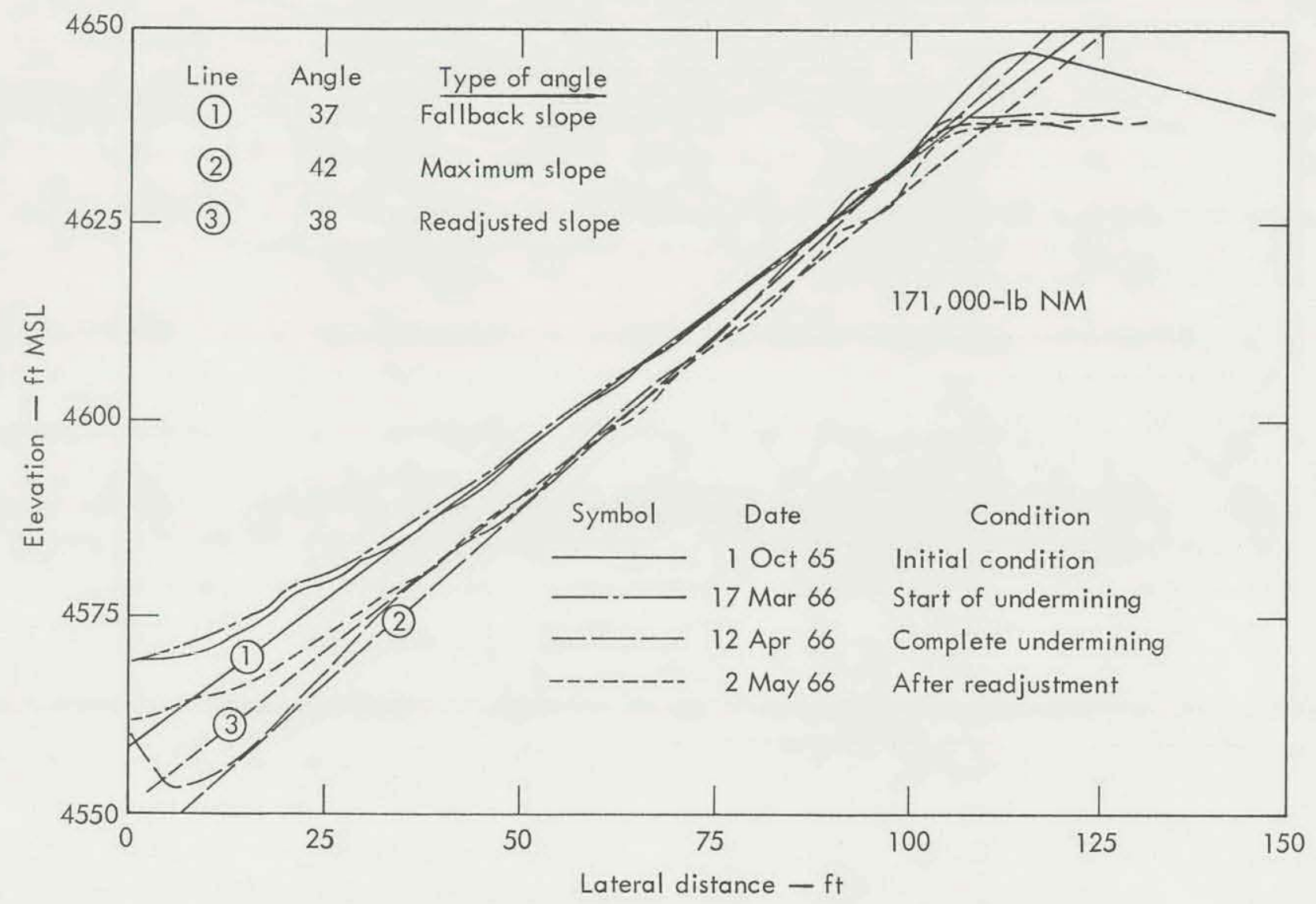

Figure 4.12 Profiles bearing S $40^{\circ} \mathrm{W}$ of apparent crater illustrating slope adjustment stages (Reference 14). 


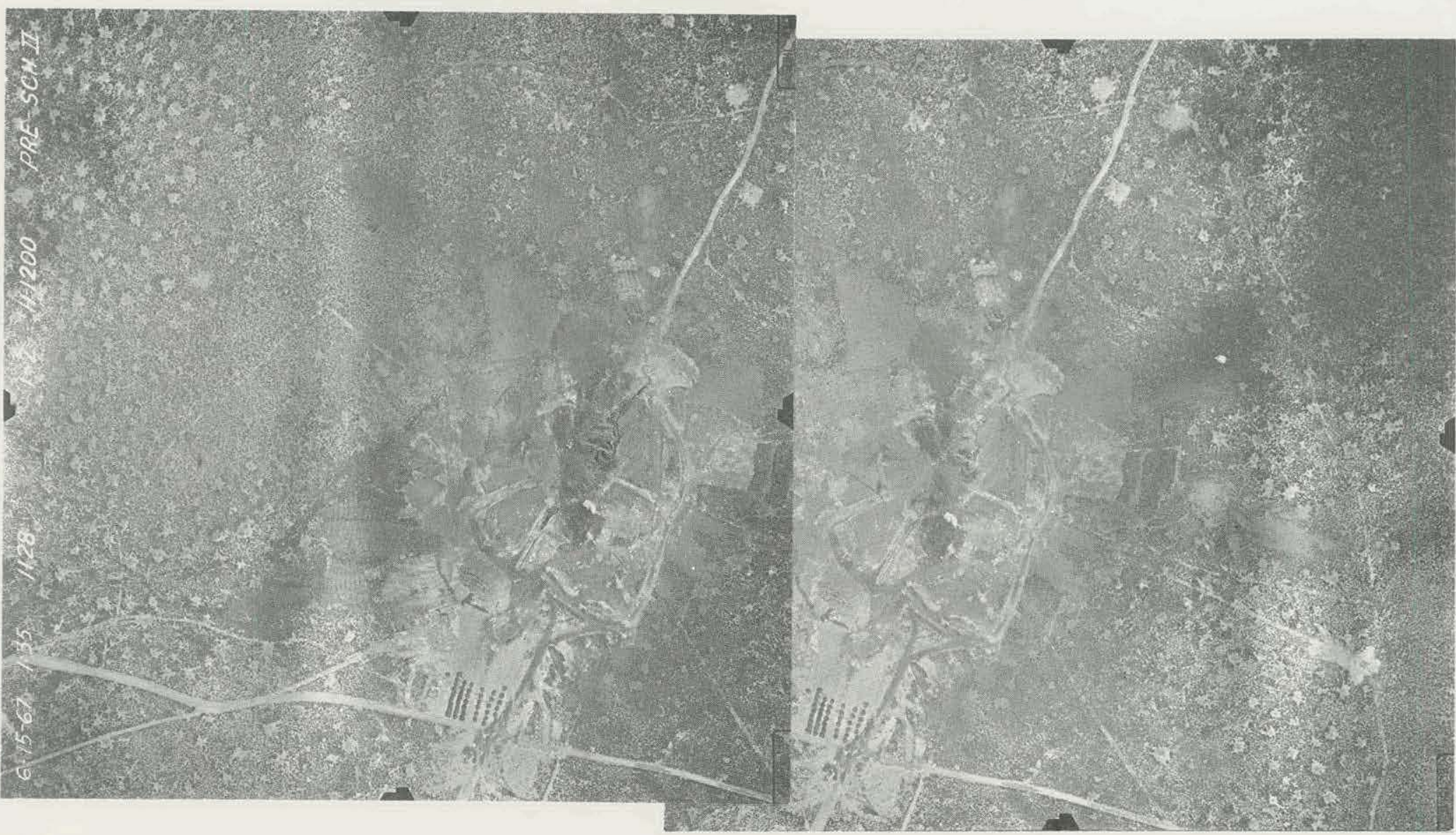

Figure 4.13 Aerial photo 14 months after completion of all excavation. 


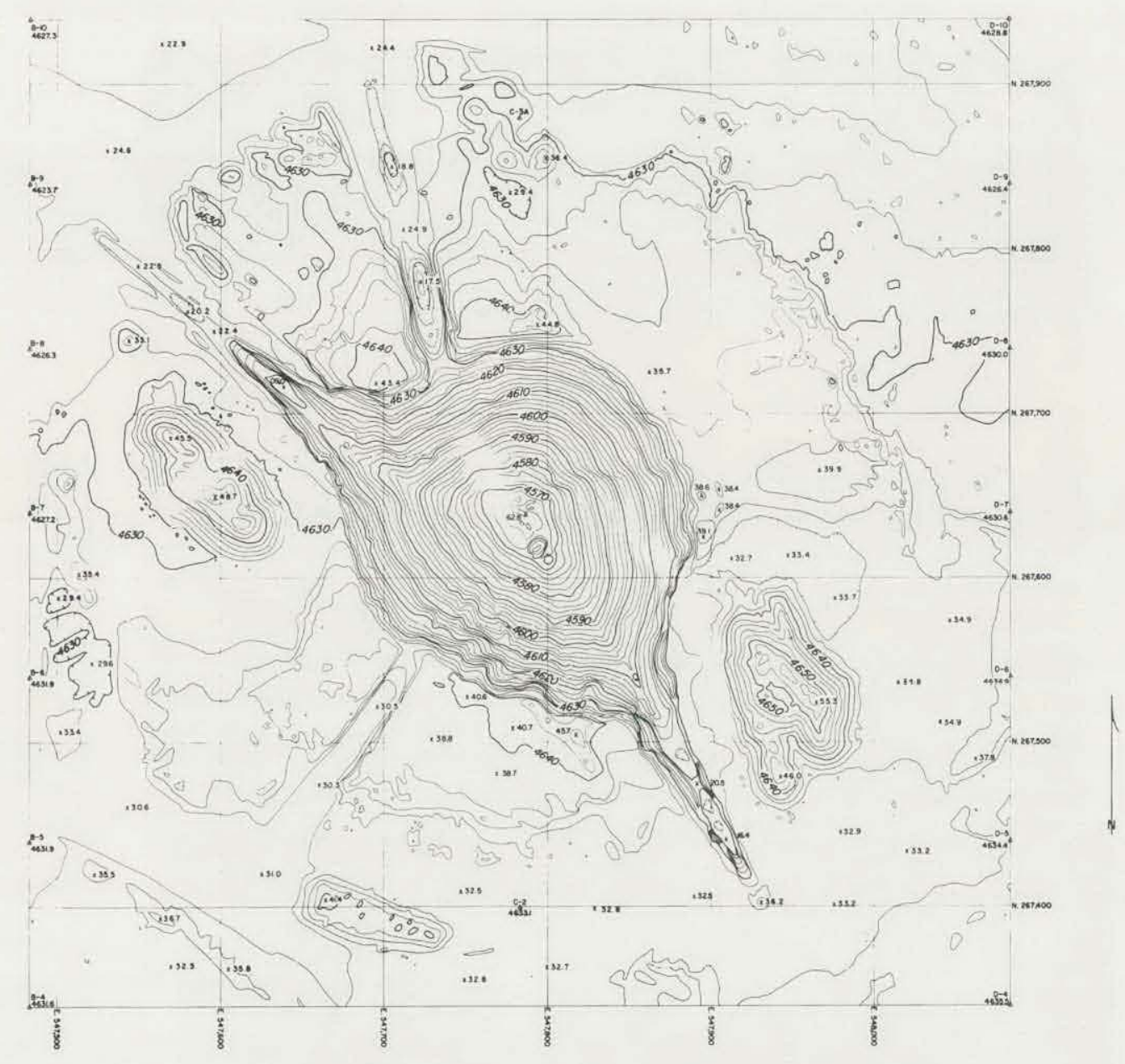

Figure 4.14 Topographic map 14 months after completion of excavation. 


\section{CHAPTER 5}

CONCLUSIONS

The following conclusions can be drawn from the results of the Pre-Schooner II postshot investigations:

1. Results obtained from the Pre-Schooner II postshot explorations indicate that the fallback materials have essentially the same characteristics as the ejecta so far as overall bulk density and block size distribution are concerned. This was also found to be the case at the Pre-Schooner I Delta crater in basalt. It is also apparent that the bulking factor varies from one hard, dry rock medium to another as evidenced by the average of 1.38 at Pre-Schooner II compared to the average of 1.66 in the Buckboard Mesa basalts (excluding Project Dugout data, a row-cratering experiment).

2. Block size distribution curves of the ejecta and fallback compared to predicted curves based on evaluation of preshot data showed relatively good correlation. This same relatively good correlation was also noted in the Buckboard Mesa basalt cratering experiments. However, the predicted curves for Pre-Schooner II were based solely on a visual examination of the access hole and shot cavity (due to the nature of the rock, core from the exploratory holes and the borehole photography were unusable for joint analysis), whereas previously predicted curves were based on averages of the lineal joint intercept of a number of borings.

3. Examination of the radial trenches showed lip upthrust ranging from 4 feet in Trench No. 2 to 17 feet in Trench No. 1. This variation was also observed at the Danny Boy crater. At Danny Boy the upthrust was exposed all around the crater and could be mapped. At Pre-Schooner II the upthrust was exposed at the south side of the crater as a result of sloughing of the fallback during excavation. Although it was not mapped along the south rim, the upthrust was observed to be highly variable.

4. Each of the lip trenches was deepened as far as possible and then examined for blast-induced fractures and increased effective porosity. Some fresh fracturing was observed close-in in all three trenches; however, the nature of the material was such that no detailed study could be made. Based on the great amount of upthrust in two of the trenches and the highly variable rupture zone bulk densities it must be concluded that there has been some increase in effective porosity.

5. The change in slope angle from the initial 37 to 42 degrees caused by excavating the fallback and then readjustment to a stable condition at 38 degrees is an indication that the initial crater formation results in relatively stable crater slopes. This means that the slopes resulting from this detonation are stable provided no disturbing forces are introduced. 
6. The postshot exploratory techniques developed to date for investigating hard, dry rock craters are only partially successful in accomplishing the major objectives. The procedures employed produce very reliable data on ejecta bulk density and block size distribution and overall fallback bulk density and block size distribution. However, these same procedures do not allow for obtaining variations of either the bulk density or block size distribution within the fallback. Determination of the true crater radius and amount of upthrust is easily established at each of the excavated trenches; however, these values vary at every point around the crater and existing exploration methods do not provide this additional data. Also, it was not possible to determine the limits of the fallback-rupture zone at depth because of the inability to obtain good core recovery in this particular rock type. 


\section{REFERENCES}

1. R. J. Lutton, F. E. Girucky, J. L. Decell and R. W. Hunt; "Preshot Geologic and Engineering Properties Investigations, Project Pre-Schooner II"; PNE-509; U. S. Army Engineer Waterways Experiment Station, Vicksburg, Mississippi (in preparation).

2. R. J. Lutton, F. E. Girucky and R. W. Hunt; "Geologic and Engineering Properties Investigations, Project Pre-Schooner"; PNE-505F; April 1967; U. S. Army Engineer Waterways Experiment Station, Vicksburg, Mississippi.

3. R. J. Lutton and F. E. Girucky; "Geologic and Engineering Properties Investigations Project Sulky"; PNE-720, November 1966; U. S. Army Engineer Waterways Experiment Station, Vicksburg, Mississippi.

4. R. J. Lutton; "Geologic and Engineering Properties Investigations, Project Dugout"; PNE-602F; U. S. Army Engineer Waterways Experiment Station, Vicksburg, Mississippi (in preparation).

5. R. C. Nugent and D. C. Banks; "Engineering-Geologic Investigations, Project Danny Boy"; PNE-5005, November 1966; U. S. Army Engineer Waterways Experiment Station, Vicksburg, Mississippi.

6. Alton D. Frandsen; "Postshot Field Investigations Buckboard Mesa, Nevada Test Site"; NCG/TM 65-4, 9 August 1965; U. S. Army Engineer Nuclear Cratering Group, Livermore, California.

7. Roger Paul; "Surface Geology of the Pre-Schooner II Area"; NCG/TM 65-3, 13 May 1965; U. S. Army Engineer Nuclear Cratering Group, Livermore, California.

8. Roger Paul; "Geologic Examination of the Access Shaft and Explosive Cavity for Project Pre-Schooner II; NCG/TM 65-11, November 1965; U. S. Army Engineer Nuclear Cratering Group, Livermore, California.

9. R. T. Stearns; Lawrence Radiation Laboratory, Livermore, personal communication, July 23, 1965.

10. S. M. Hansen, N. M. Short, and D. E. Rawson; "Report of Preliminary Geologic Investigations of the Proposed Schooner Site Bruneau Canyon, Idaho"; 4 October 1963; Lawrence Radiation Laboratory, Livermore.

11. L. M. Gard and J. W. Hasler; "Geology of Proposed Schooner Site, Bruneau River Area, Owyhee County, Idaho"; USGS Technical Letter, Schooner -3;

25 September 1963; U. S. Geological Survey, Denver, Colorado.

12. B. C. Hughes; "Project Pre-Schooner II Technical Director's Summary Report"; PNE-507, December 1965; U. S. Army Engineer Nuclear Cratering Group, Livermore, California. 
13. P. R. Fisher and R. Paul; "Prediction of Fallback and Ejecta Block Size Distribution - Project Pre-Schooner II"; NCG 65-317, 27 September 1965; U. S. Army Engineer Nuclear Cratering Group, Livermore, California.

14. B. N. MacIver; "Formation and Initial Stability of Slopes on Cohesionless Materials"; PNE-5009, August 1967; U. S. Army Engineer Waterways Experiment Station, Vicksburg, Mississippi. 
APPENDIX A

\section{RESULTS OF PRESHOT UPHOLE SEISMIC SURVEY}

(Extracted from Lawrence Radiation Laboratory Internal Memorandum, R. T. Stearns to A. Holzer, dated 23 July 1965) 
TABLE A1 SEISMIC UPHOLE SURVEY

\begin{tabular}{|c|c|c|c|c|c|c|c|}
\hline $\begin{array}{c}\text { Shot } \\
\text { No. }\end{array}$ & $\begin{array}{c}\text { Shot } \\
\text { Depth } \\
D_{\mathrm{S}}\end{array}$ & $\begin{array}{l}\text { Slant Distance } \\
\left(\mathrm{D}_{\mathrm{s}}^{2}+\mathrm{o} / \mathrm{s}^{2}\right)^{1 / 2}\end{array}$ & $\begin{array}{c}\text { Time } \\
\text { from Shot } \\
\text { to Geophone } \\
\mathrm{T}_{\mathrm{sd}} \\
\end{array}$ & $\begin{array}{l}\text { Average } \\
\text { Velocity } \\
\text { from Shot } \\
\text { to Surface }\end{array}$ & $\Delta \mathrm{D}$ & $\Delta \mathrm{T}$ & $\begin{array}{l}\text { Internal } \\
\text { Velocity }\end{array}$ \\
\hline & feet & feet & $\mathrm{sec}$ & $\mathrm{ft} / \mathrm{sec}$ & feet & sec & $\mathrm{ft} / \mathrm{sec}$ \\
\hline 1 & 108.0 & 108.00 & 0.0166 & 6,510 & \multirow{3}{*}{$\begin{array}{l}9.6^{\mathrm{a}} \\
9.8\end{array}$} & \multirow{3}{*}{$\begin{array}{l}0.0007^{\mathrm{a}} \\
0.0006\end{array}$} & \multirow{3}{*}{$\begin{array}{l}13,714^{a} \\
16,333\end{array}$} \\
\hline 2 & 98.0 & 98.40 & 0.0159 & 6,180 & & & \\
\hline 3 & 88.0 & 88.60 & 0.0153 & 5,790 & & & \\
\hline 4 & 78.0 & 78.70 & Misfire & No data & 19.9 & 0.0023 & 8,652 \\
\hline 5 & 68.0 & 68.70 & 0.0130 & 5,280 & \multirow{2}{*}{9.8} & 0.0014 & 7,000 \\
\hline 6 & 58.0 & 58.90 & 0.0116 & 5,075 & & 0.0012 & 8,083 \\
\hline 7 & 48.0 & 49.20 & 0.0104 & 4,725 & $\begin{array}{l}9.1 \\
9.9\end{array}$ & \multirow{2}{*}{$\begin{array}{l}0.0015 \\
0.0017\end{array}$} & 6,600 \\
\hline 8 & 38.0 & 39.30 & 0.0089 & 4,420 & \multirow{2}{*}{9.5} & & 5,588 \\
\hline 9 & 28.0 & 29.80 & 0.0072 & 4,320 & & \multirow{3}{*}{$\begin{array}{l}0.0017 \\
0.0014\end{array}$} & \multirow{3}{*}{$\begin{array}{l}5,411 \\
5,571 \\
2,850\end{array}$} \\
\hline 10 & 18.0 & 20.60 & 0.0055 & 3,750 & \multirow{2}{*}{7.8} & & \\
\hline 11 & 8.0 & 12.80 & 0.0041 & 2,850 & & & \\
\hline & 0 & 0 & & & & & \\
\hline
\end{tabular}

${ }^{\text {a }}$ Entry in this column is read between the two depths shown in Shot Depth column at left. 


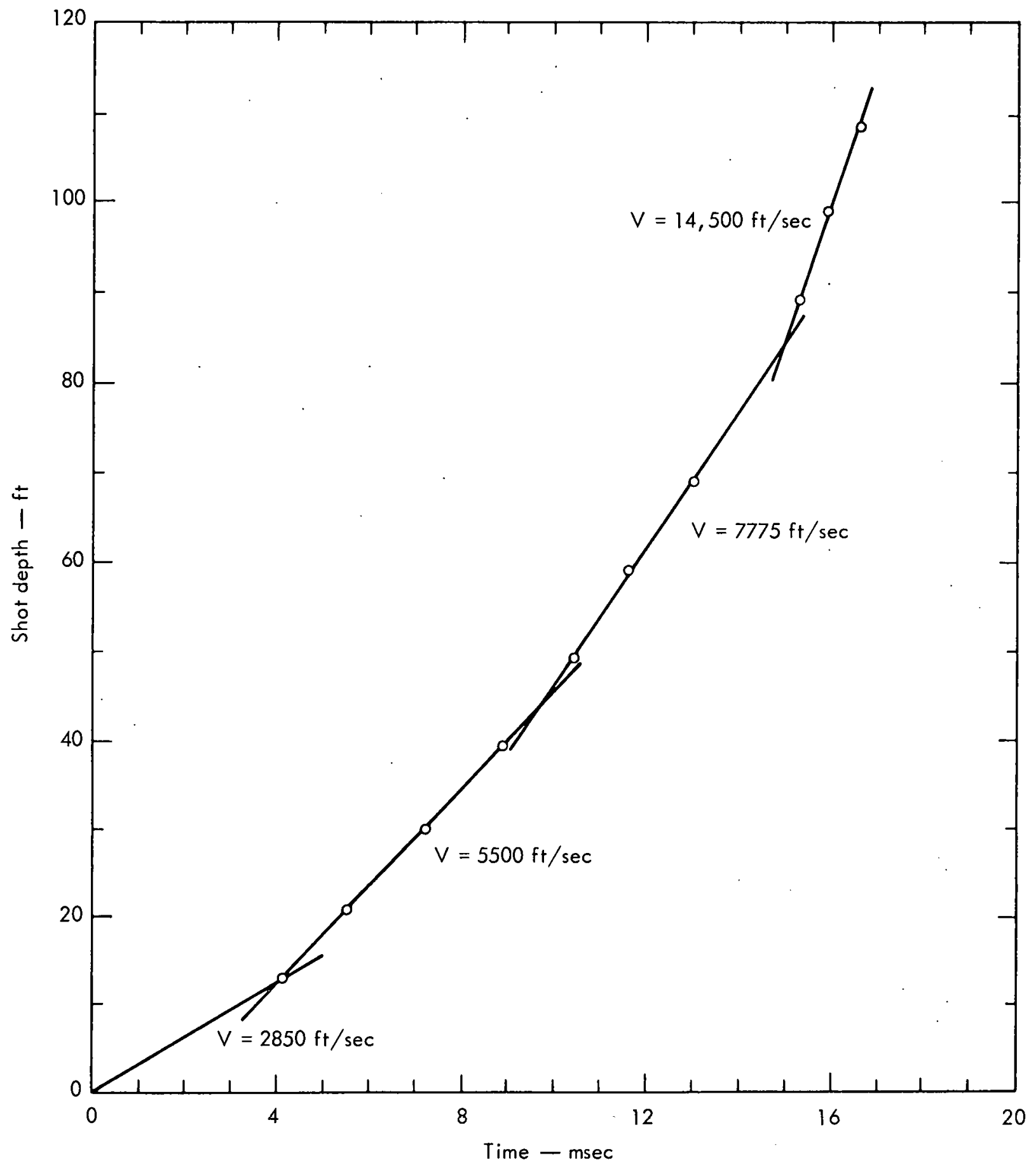

Figure A1 Average velocities (slant-distance corrected) 


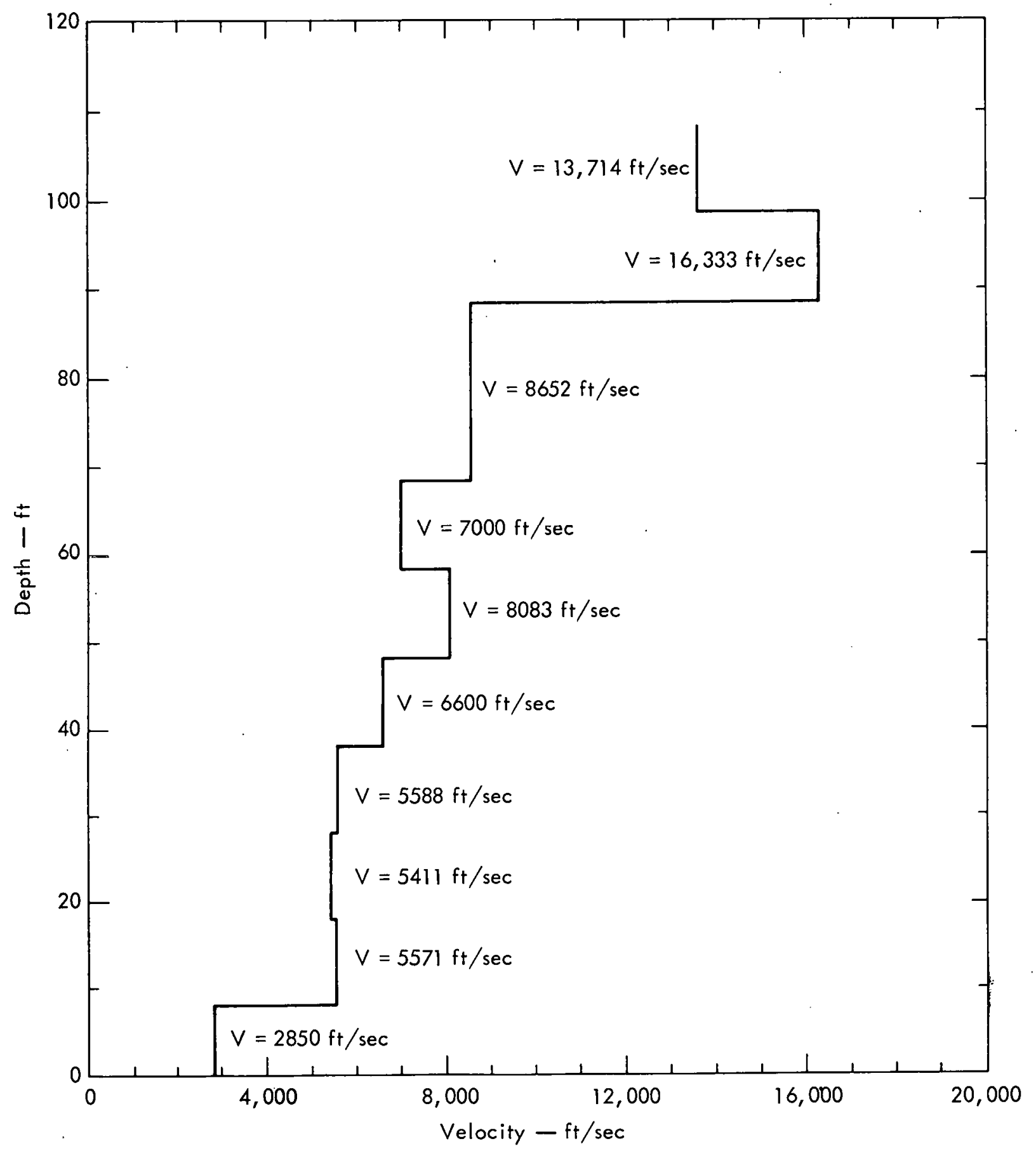

Figure A2 Internal velocities. 


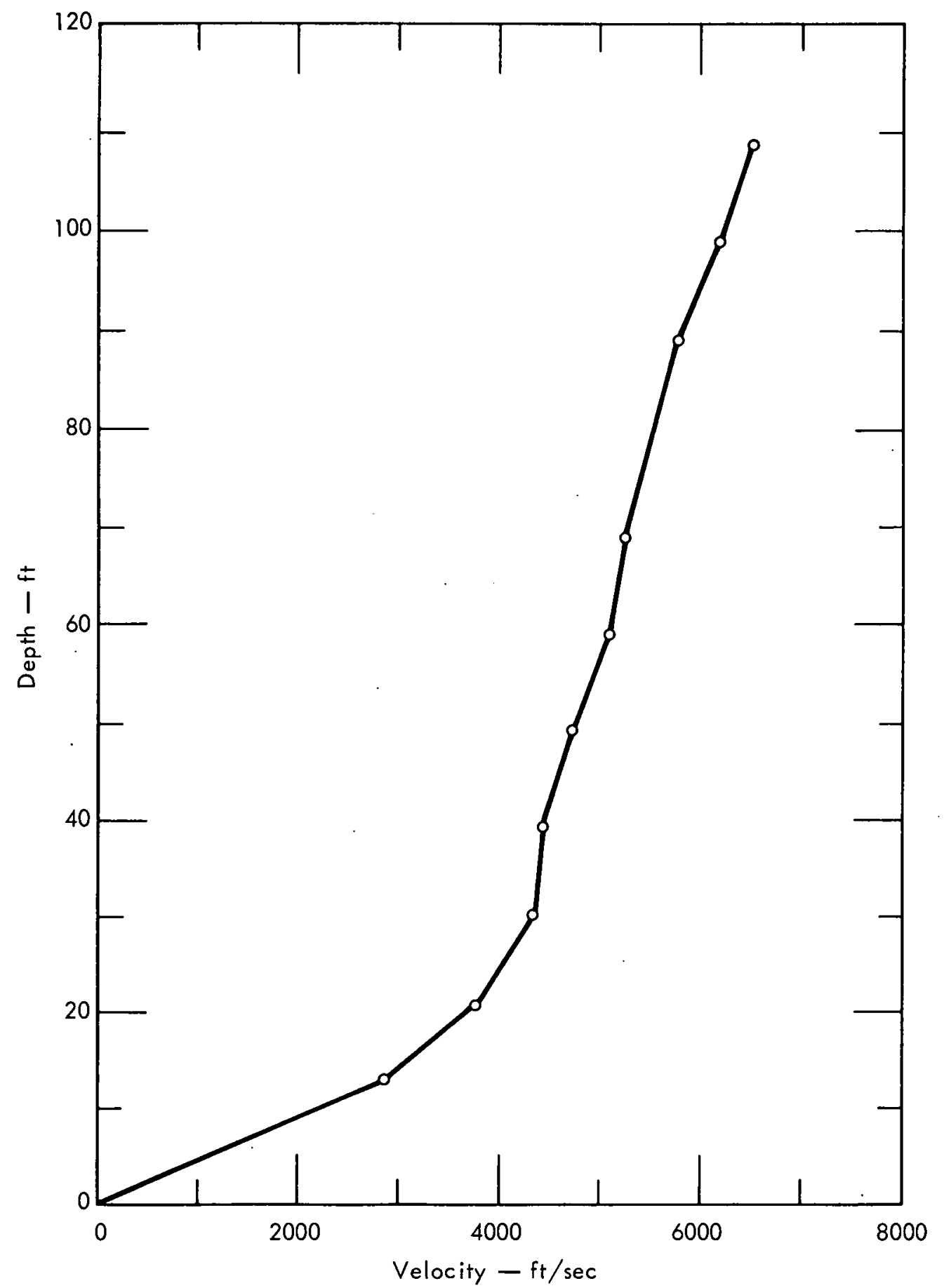

Figure A3 Average velocities from shot to surface (slant-distance corrected). 
APPENDIX B

PRESHOT BORING LOGS OF

PRE-SCHOONER II SITE AREA 
BORING 2.1
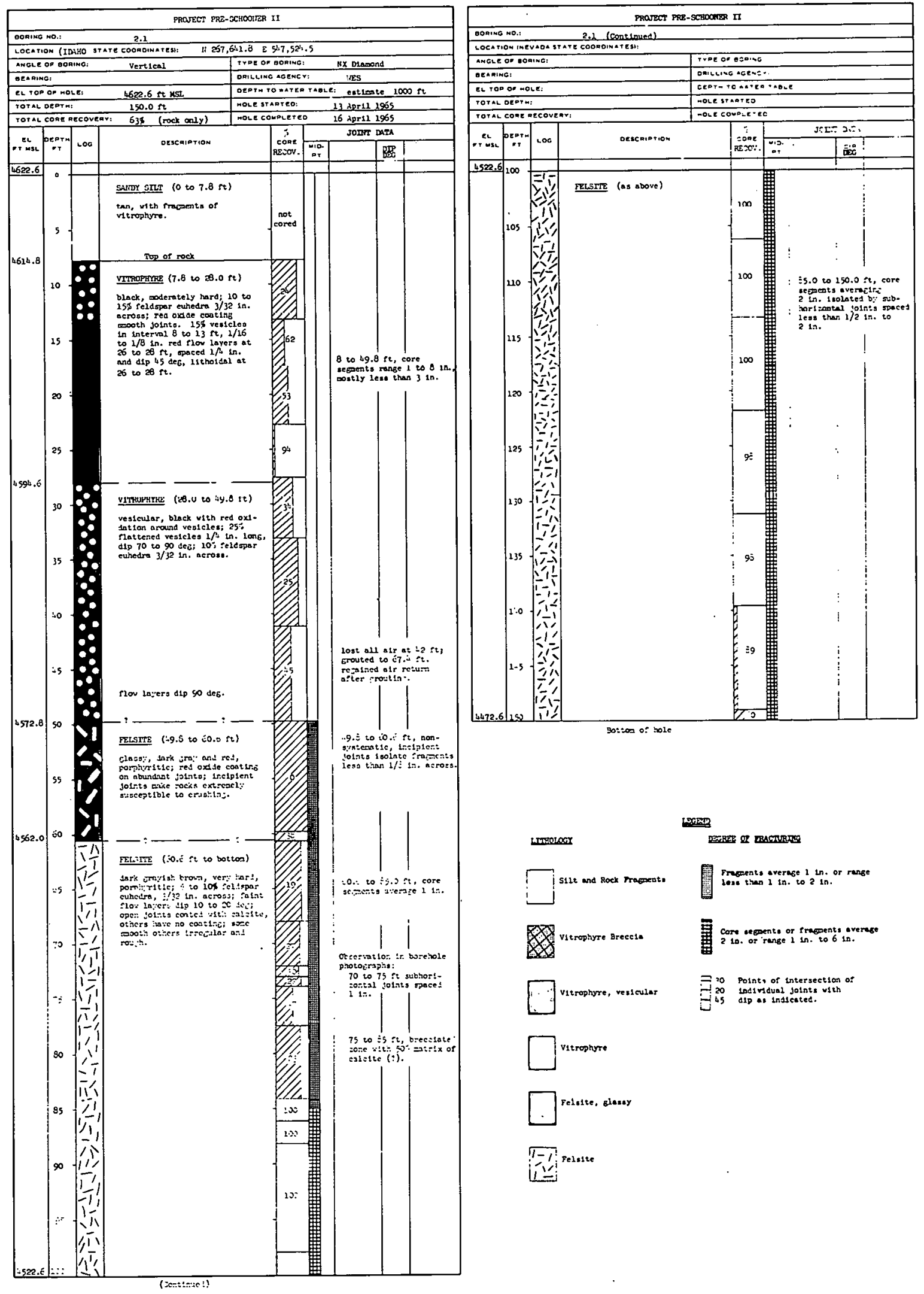
BORING 2.7
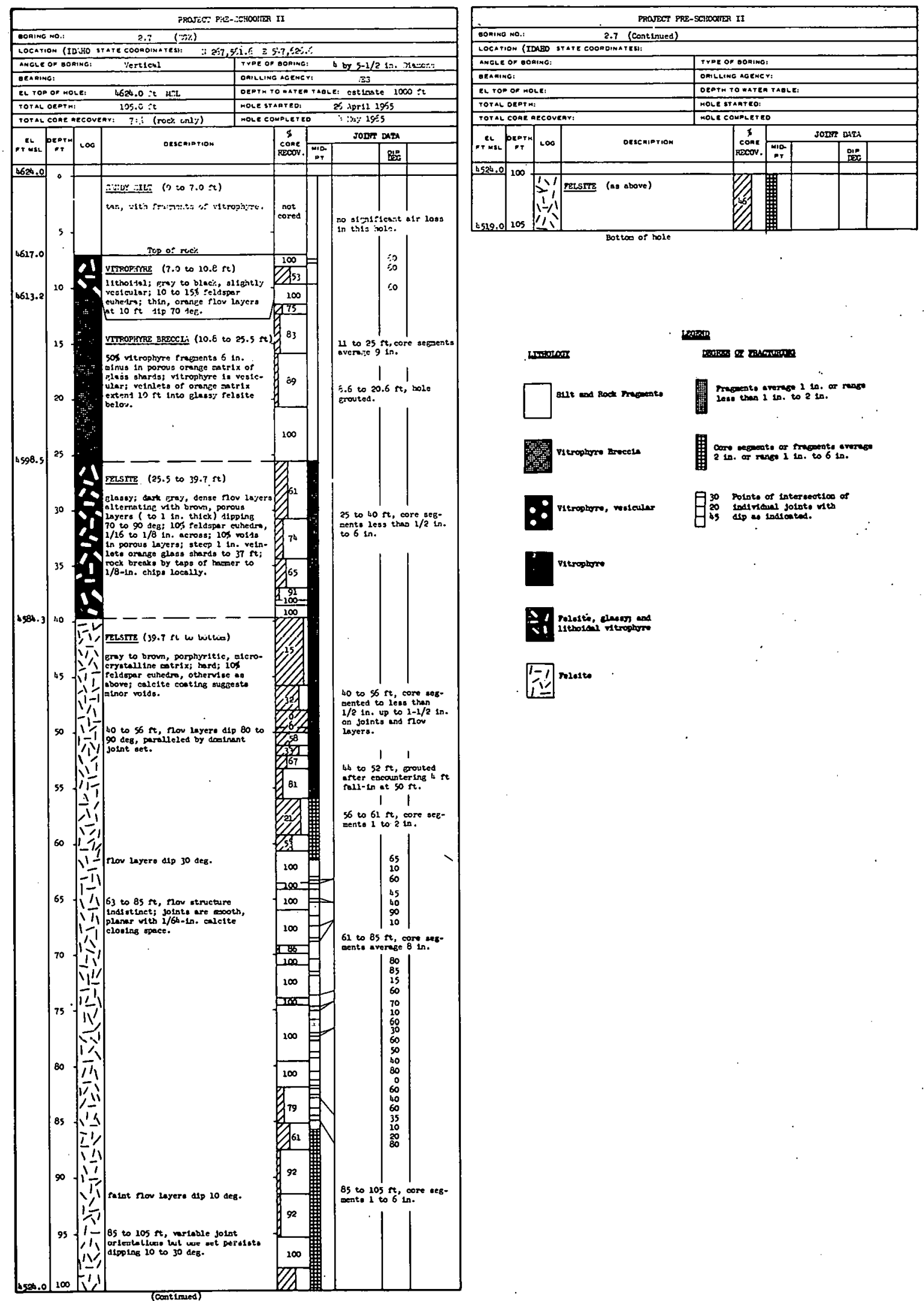

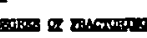

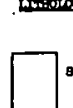

Lriogs

$\square$

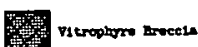

$\because$ vitroptore, molculer

?. Titrogerom

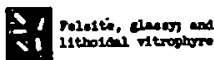

II mo1to

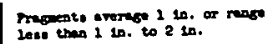

2 10. or rene 1 in. to 6 in.

30 Polste of intersertico of

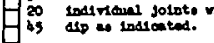




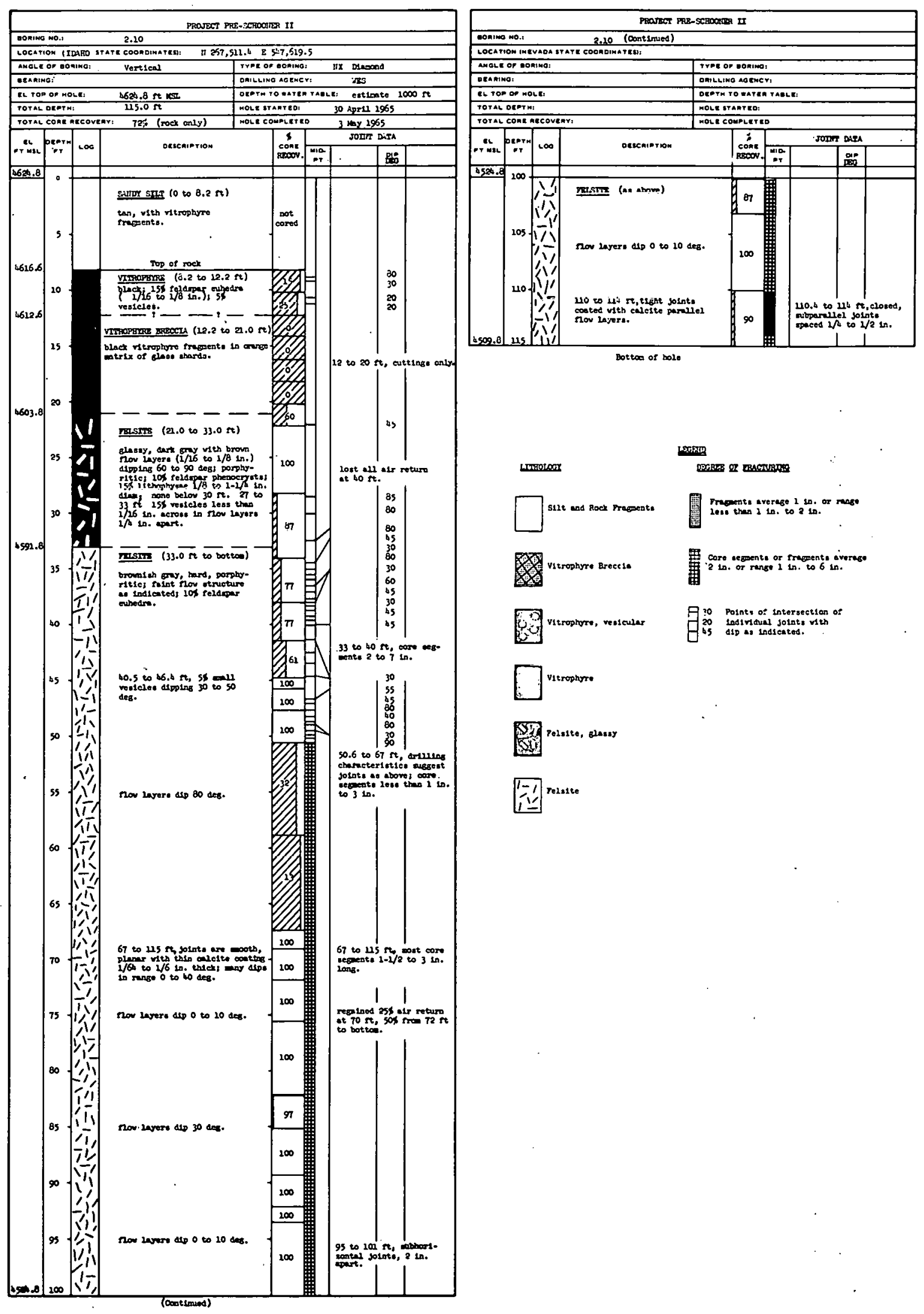


BORING 2.11
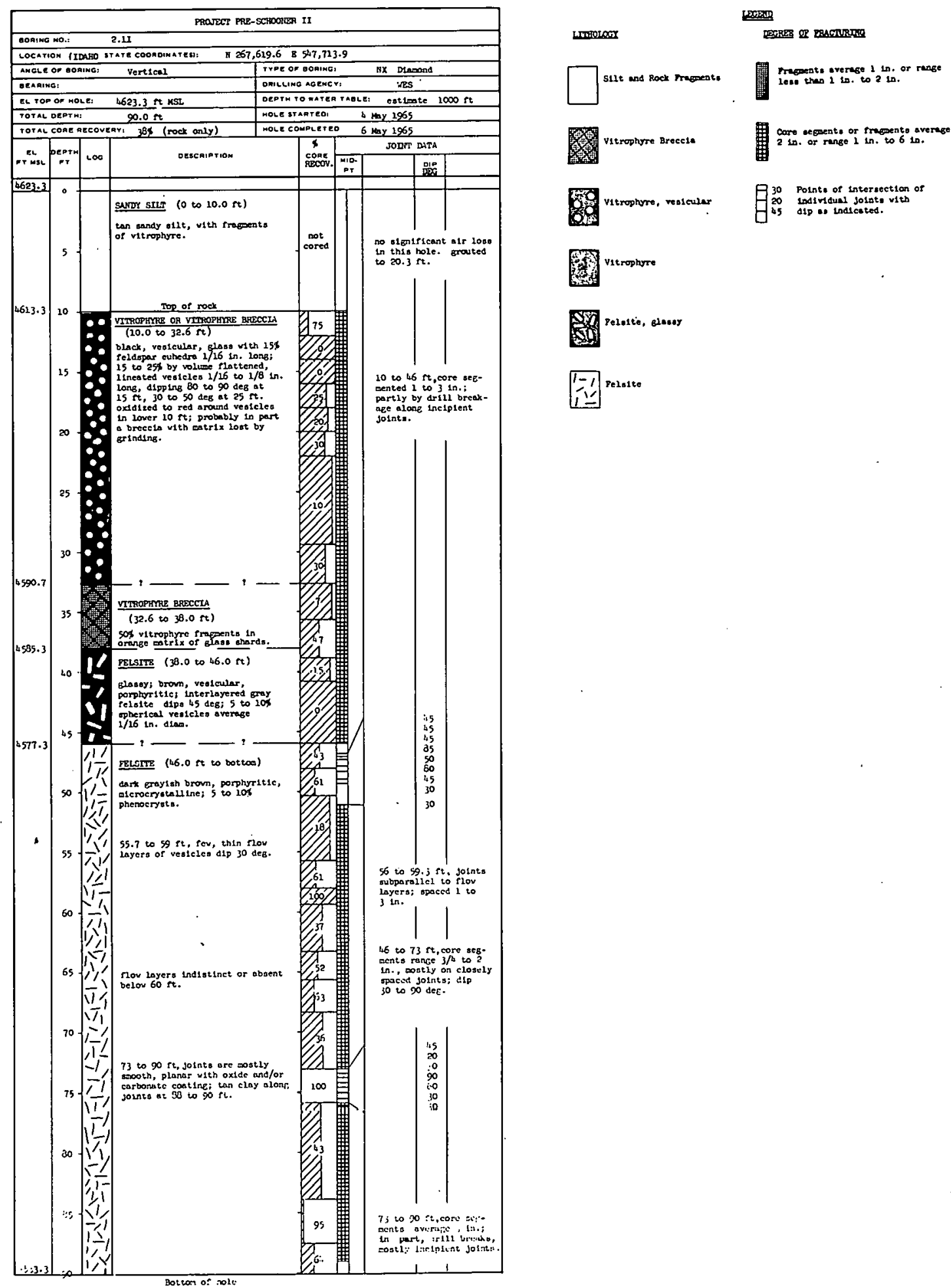
BORING 2.12
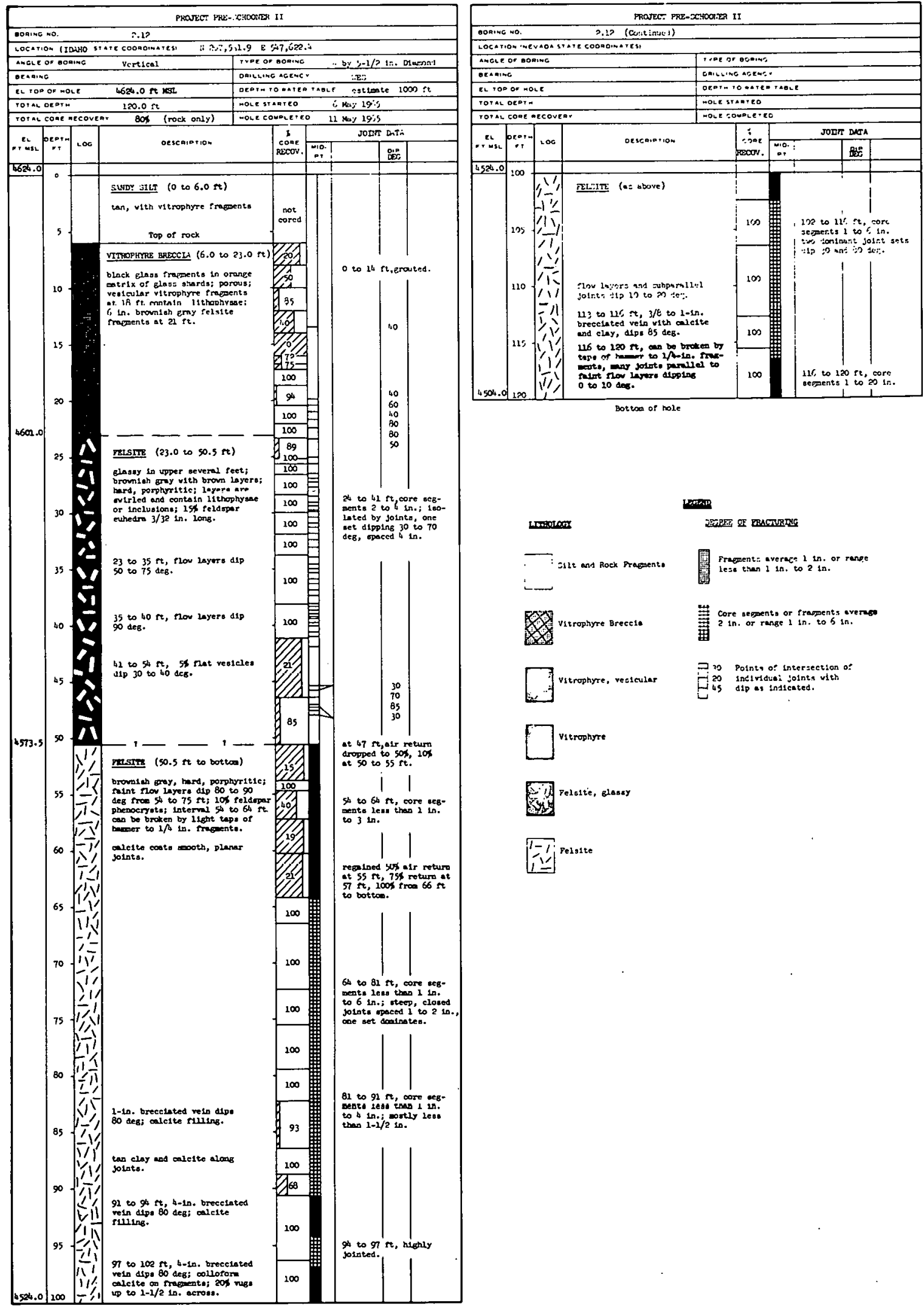

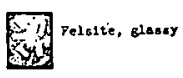

售 Pel sate 


\section{APPENDIX C}

PRE-SCHOONER II TECHNICAL REPORTS

Title of Report

Technical Director's Summary Report

Apparent Crater Studies

Preshot Geologic Investigations and Engineering Properties

Design and Postshot Evaluation of Access Hole Stemming

Base Surge and Cloud Formation

Air Blast Measurements

Surface Motion

Measurements

Ground Shock

Measurements

Subsurface Effects

Measurements

Postshot Geologic

Investigations and

Engineering Properties
Author and/or Technical Program Officer

B. C. Hughes et al.

R. H. Benfer

W. C. Sherman, Jr./

R: A. Paul et al.

WES

K. L. Saucier

NCG/LRL

$\mathrm{SC}$

NCG

W. C. Day/R. F. Rohrer

L. J. Vortman/

J. W. Reed

K. L. Larner

L. L. Davis

Roland F.

Beers, Inc.

LRL

M. Heusinkveld/

R. E. Marks

NCG

A. D. Frandsen
PNE-510

Report

Number

PNE-507

PNE-508

PNE-509

PNE -511

$\mathrm{PNE}-512$

PNE-513

PNE-514

PNE-5i5

PNE-516 


\section{LRL Internal Distribution}

Michael M. May

R. Batzel

J. Bell

J. Carothers

W. Decker

S. Fernbach

H. L. Reynolds

J. Gofman

E. Goldberg

J. Hadley

W. Harford

C. Haussmann

P. Moulthrop

G. Higgins

A. Holzer

E. Hulse

J. Kane

J. Knox

J. Kury

F. Eby

M. Nordyke

J. Rosengren

B. Rubin

D. Sewell

P. Steveneson

H. Tewes

C. Van Atta

G. Werth

TID Berkeley

D. M. Wilkes, Berkeley

E. Teller, Berkeley

L. Crooks, Mercury

TID File 


\section{External Distribution}

D. J. Convey

Department of Mines and Technical Surveys

Canada

G. W. Govier

Oil and Gas Conservation Board

Canada

U. S. Army Engineer Division, Lower Mississippi Valley

Vicksburg, Mississippi

U. S. Army Engineer District, Memphis

Memphis, Tennessee

U. S. Army Engineer District, New Orleans

New Orleans, Louisiana

U. S. Army Engineer Waterways Experiment Station

Vicksburg, Mississippi

U. S. Army Engineer District, St. Louis

St. Louis, Missouri

U. S. Army Engineer District, Vicksburg

Vicksburg, Mississippi

U. S. Army Engineer Division, Mediterranean

APO, New York.

U. S. Army Liaison Detachment

New York, New York

U. S. Army Engineer District, GULF

APO, New York

U. S. Army Engineer Division, Missouri River

Omaha, Nebraska

U. S. Army Engineer District, Kansas City

Kansas City, Missouri

U. S. Army Engineer District, Omaha

Omaha, Nebraska

U. S. Army Engineer Division, New England

Waltham, Massachusetts

U. S. Army Engineer Division, North Atlantic New York, New York

U. S. Army Engineer District, Baltimore

Baltimore, Maryland

U. S. Army Engineer District, New York

New York, New York

U. S. Army Engineer District, Norfolk

Norfolk, Virginia 
External Distribution (Continued)

U. S. Army Engineer District, Philadelphia Philadelphia, Pennsylvania

U. S. Army Engineer Division, North Central Chicago, Illinois

U. S. Army Engineer District, Buffalo Buffalo, New York

U. S. Army Engineer District, Chicago Chicago, Illinois

U. S. Army Engineer District, Detroit Detroit, Michigan

U. S. Army Engineer District, Rock Island Rock Island, Illinois

U. S. Army Engineer District, St. Paul

St. Paul, Minnesota

U. S. Army Engineer District, Lake Survey Detroit, Michigan

U. S. Army Engineer Division, North Pacific Portland, Oregon

U. S. Army Engineer District, Portland Portland, Oregon

U. S. Army Engineer District, Alaska Anchorage, Alaska

U. S. Army Engineer, Seattle Seattle, Washington

U. S. Army Engineer District, Walla Walla Walla Walla, Washington

U. S. Army Engineer Division, Ohio River Cincinnati, Ohio

U. S. Army Engineer District, Huntingdon Huntington, West Virginia

U. S. Army Engineer District, Louisville Louisville, Kentucky

U. S. Army Engineer District, Nashville Nashville, Tennessee

U. S. Army Engineer District, Pittsburgh Pittsburgh, Pennsylvania

U. S. Army Engineer Division, Pacific Ocean Honolulu, Hawaii

U. S. Army Engineer District, Far East APO, San Francisco, California 
External Distribution (Continued)

U. S. Army Engineer District, Honolulu Honolulu, Hawaii

U. S. Army Engineer District, Okinawa APO, San Francisco, California

U. S. Army Engineer Division, South Atlantic Atlanta, Georgia

U. S. Army Engineer District, Canaveral Merritt Island, Florida

U. S. Army Engineer District, Charleston Charleston, South Carolina

U. S. Army Engineer District, Jacksonville Jacksonville, Florida

U. S. Army Engineer District, Mobile Mobile, Alabama

U. S. Army Engineer District, Savannah Savannah, Georgia

U. S. Army Engineer District, Wilmington Wilmington, North Carolina

U. S. Army Engineer Division, South Pacific San Francisco, California

U. S. Army Engineer District, Los Angeles Los Angeles, California

U. S. Army Engineer District, Sacramento Sacramento, California

U. S. Army Engineer District, San Francisco San Francisco, California

U. S. Army Engineer Division, Southwestern Dallas, Texas

U. S. Army Engineer District, Albuquerque Albuquerque, New Mexico

U. S. Army Engineer District, Fort Worth Fort Worth, Texas

U. S. Army Engineer District, Galveston Galveston, Texas

U. S. Army Engineer District, Little Rock

Little Rock, Arkansas

U. S. Army Engineer District, Tulsa

Tulsa, Oklahoma

U. S. Army Coastal Engineering Research Board Washington, D. C. 


\section{External Distribution (Continued)}

Mississippi River Commission

Vicksburg, Mississippi

Rivers and Harbors, Boards of Engineers

Washington, D. C.

Corps of Engineers Ballistic Missile Construction Office Norton Air Force Base, California

U. S. Army Engineer Center

Ft. Belvoir, Virginia

U. S. Army Engineer Reactors Group

Ft. Belvoir, Virginia

U. S. Army Engineer Training Center

Ft. Leonard Wood, Missouri

U. S. Army Engineer School

Ft. Belvoir, Virginia

U. S. Army Engineer Nuclear Cratering Group

Livermore, California

TID-4500, UC-35, Nuclear Explosions - Peaceful Applications Neither the United Stotes, not the Commission. nor any person acting on behalt al the Connaission:

A. Makes any wartally or representation, expressed of implied. with respect to the accuracy. completeness. or usefulness of the information copthined in this report. or that the use of ary inlornation, apparatus. method. or process disclosed in this repott may not inftringe privately owned rights; or

B. Assunes any liabilities with respecl to the use ol. or tor danages resulling from the use of any information, apparatus, method of process dis. closed in this report

As used in the above. "persan acting on behall of the Commission" includes ony employee or contractos of the Commission. of employee of such or empoyee ol such contacto

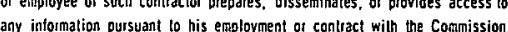
any information pursuant to his employment or conliact wilh the Corrnission. ol his employnenl with such contractor.

WF:rd 
